medRxiv preprint doi: https://doi.org/10.1101/2022.02.07.22270514; this version posted February 8, 2022. The copyright holder for this preprint (which was not certified by peer review) is the author/funder, who has granted medRxiv a license to display the preprint in perpetuity.

Gastric Dysfunction in NVS

All rights reserved. No reuse allowed without permission.

\title{
Gastric dysfunction in patients with chronic nausea and vomiting syndromes defined by a novel non-invasive gastric mapping device
}

\section{Authors and Institutions:}

Armen A. Gharibans, $\mathrm{PhD}^{\star 1,2,3}$, Stefan Calder, $\mathrm{PhD}^{\star 1,2}$, Chris Varghese, BMedSc(Hons) ${ }^{1}$, Stephen

Waite, $\mathrm{PhD}^{2}$, Gabriel Schamberg, $\mathrm{PhD}^{2}$, Charlotte Daker, FRACP ${ }^{4}$, Peng Du, PhD ${ }^{2,3}$, Saeed

Alighaleh, $\mathrm{PhD}^{2}$, Daniel Carson, $\mathrm{MBChB}^{1}$, Jonathan Woodhead, $\mathrm{PhD}^{2}$, Gianrico Farrugia, $\mathrm{MD}^{5}$, John

A. Windsor, FRACS ${ }^{1}$, Christopher N. Andrews, FRCPC ${ }^{6}$, Greg O'Grady, FRACS ${ }^{1,2,3}$

* Joint first authors

1. Surgical and Translational Research Centre, the University of Auckland, New Zealand

2. Alimetry Ltd, Auckland, New Zealand

3. Auckland Bioengineering Institute, The University of Auckland, New Zealand

4. Department of Gastroenterology, North Shore Hospital, Auckland, New Zealand

5. Mayo Clinic, Rochester, MN, USA

6. Division of Gastroenterology, Cumming School of Medicine, University of Calgary, Canada

\section{Corresponding Author}

Professor Greg O'Grady

Department of Surgery

University of Auckland

Auckland, New Zealand

greg.ogrady@auckland.ac.nz 
medRxiv preprint doi: https://doi.org/10.1101/2022.02.07.22270514; this version posted February 8, 2022. The copyright holder for this preprint (which was not certified by peer review) is the author/funder, who has granted medRxiv a license to display the preprint in All rights reserved. No reuse allowed without permission.

Gastric Dysfunction in NVS

Gharibans \& Calder et al. 2022.

\section{Key Points}

Question: How does body surface gastric mapping, a novel non-invasive medical device for evaluating gastric motility, aid assessment of patients with chronic nausea and vomiting.

Findings: Two subgroups were revealed in chronic nausea and vomiting syndromes, which could not be differentiated by symptoms alone. Where body surface gastric mapping was normal, symptoms correlated with psychological comorbidities, and where body surface gastric mapping was abnormal, symptoms correlated with gastric electrophysiology metrics.

Meaning: Distinct phenotypes revealed by body surface gastric mapping correlate with symptoms, which should inform targeted clinical management and allocations into therapeutic trials. 
medRxiv preprint doi: https://doi.org/10.1101/2022.02.07.22270514; this version posted February 8, 2022. The copyright holder for this preprint (which was not certified by peer review) is the author/funder, who has granted medRxiv a license to display the preprint in

All rights reserved. No reuse allowed without permission.

Gastric Dysfunction in NVS

\section{Abstract}

$\underline{\text { Importance }}$

Chronic nausea and vomiting syndromes (NVS) are prevalent and debilitating disorders. Putative mechanisms include gastric neuromuscular disease and dysregulation of brain-gut interaction, but clinical tests for objectively defining gastric motor function are lacking.

\section{$\underline{\text { Objective }}$}

A novel medical device enabling non-invasive body surface gastric mapping (BSGM) was developed and applied to evaluate NVS pathophysiology.

\section{Design}

A case-control study where BSGM was performed in NVS patients and matched controls using Gastric Alimetry (Alimetry, New Zealand), comprising a conformable high-resolution array (8x8 electrodes; $20 \mathrm{~mm}$ inter-electrode spacing), wearable Reader, and validated symptom logging App. Continuous measurement encompassed a fasting baseline (30 min), $482 \mathrm{kCal}$ meal (10 min), and 4-hr post-prandial recording.

\section{Setting}

Multicenter study in Auckland, New Zealand and Calgary, Canada.

\section{$\underline{\text { Participants }}$}

43 NVS patients (gastroparesis and Rome IV chronic NVS) and 43 matched controls.

\section{Main outcomes and measures}

Symptom severity and quality of life were measured using Patient Assessment of Upper

Gastrointestinal Disorders-Symptom Severity Index (PAGI-SYM), Gastroparesis Cardinal Symptom Index (GCSI), and Patient Assessment of Upper Gastrointestinal Disorders-Quality of Life (PAGIQOL) instruments. Health psychology metrics included the State Trait Anxiety Inventory Short Form (STAI-SF) and Patient Health Questionnaire-2 (PHQ-2) questionnaires. Spectral analyses including frequency, amplitude, and fed-fasting power ratio. Spatial biomarker analyses included spatial frequency stability and average spatial covariance.

\section{$\underline{\text { Results }}$}

Meal responses were impaired in NVS, with reduced amplitudes compared to controls (median 23.3 vs $38.0 \mu \mathrm{V}, \mathrm{p}<0.001$ ), impaired fed-fasting power-ratios (1.1 vs 1.6, $\mathrm{p}=0.02$ ), and disorganized slowwaves (spatial frequency stability 13.6 vs $49.5 ; p<0.001$ ). However, two distinct NVS subgroups were 
medRxiv preprint doi: https://doi.org/10.1101/2022.02.07.22270514; this version posted February 8, 2022. The copyright holder for this preprint (which was not certified by peer review) is the author/funder, who has granted medRxiv a license to display the preprint in All rights reserved. No reuse allowed without permission.

Gastric Dysfunction in NVS

Gharibans \& Calder et al. 2022.

evident with indistinguishable symptoms (all p>0.05). A majority (62\%) had normal BSGM studies (all biomarkers non-significant vs controls) with increased psychological comorbidities (43.5\% vs $7.7 \%$; $\mathrm{p}=0.03$ ) and anxiety scores (median 16.5 vs $13.0 ; \mathrm{p}=0.035$ ). A smaller subgroup (31\%) had markedly abnormal BSGM, with test biomarkers correlating with symptoms (nausea, pain, excessive fullness, early satiety, bloating; all $r>0.35, p<0.05)$.

\section{$\underline{\text { Conclusions and Relevance }}$}

NVS patients share overlapping symptoms, but comprise distinct underlying phenotypes as revealed by a novel BSGM device. These phenotypes correlate with symptoms, which should inform clinical management and allocations into therapeutic trials.

\section{Keywords}

Gastroparesis, chronic nausea and vomiting syndromes, high-resolution electrogastrography, body surface gastric mapping, functional dyspepsia 
medRxiv preprint doi: https://doi.org/10.1101/2022.02.07.22270514; this version posted February 8, 2022. The copyright holder for this preprint (which was not certified by peer review) is the author/funder, who has granted medRxiv a license to display the preprint in

All rights reserved. No reuse allowed without permission.

Gastric Dysfunction in NVS

\section{Introduction}

Gastroparesis and chronic nausea and vomiting syndrome (CNVS; defined by Rome IV Criteria) are debilitating disorders with a combined global prevalence of $>1 \% .^{1-3}$ These disorders overlap, sharing similar epidemiology, symptomatology, and quality of life impacts, and impart a growing healthcare burden. ${ }^{3-7}$ Although differentiated by the presence or absence of delayed gastric emptying, this distinction is controversial because gastric emptying is unstable over time, correlates weakly with symptoms, and may not reflect the primary disease mechanism. ${ }^{8-12}$ The two disorders may therefore be considered together under the umbrella term nausea and vomiting syndromes (NVS). ${ }^{13}$

The heterogeneous and unclear pathophysiology of NVS contributes to diagnostic uncertainty and impedes therapeutic progress. Contributing mechanisms may include gastric neuromuscular dysfunction, dysregulation of gut-brain interaction, and pylorospasm, which could represent distinct or overlapping phenotypes. ${ }^{7,14,15}$ Previous investigations have identified gastric neuromuscular pathologies in subsets of patients with both gastroparesis and CNVS, suggesting they may lie on the same disease spectrum. ${ }^{7,11,16-18}$ A dominant feature has been interstitial cell of Cajal (ICC) depletion, associated with changes in proinflammatory macrophages, ${ }^{11,16,17,19}$ which has been linked to aberrant gastric electrical patterns recorded using high-resolution (HR) electrical mapping. ${ }^{16,17,20,21}$

Electrogastrography (EGG) has previously been the only clinical method for evaluating gastric myoelectrical function. EGG has demonstrated consistent abnormalities in NVS, ${ }^{13}$ however multiple limitations restricted clinical adoption, including noise susceptibility, low resolution in the face of gastric anatomical variability, inability to evaluate spatial patterns, and low specificity for disease subtypes..$^{22,23}$ Body surface gastric mapping (BSGM; also HR-EGG) has recently emerged as a new approach, employing dense fields of electrodes to reliably assess gastric activity at high spatial resolution. ${ }^{22}$ Recent studies have shown that BSGM biomarkers achieve improved sensitivity and superior symptom correlations compared to EGG and gastric emptying testing. ${ }^{24,25}$ BSGM has been comprehensively validated, and a scalable platform introduced, now enabling clinical translation. ${ }^{26,27}$ 
medRxiv preprint doi: https://doi.org/10.1101/2022.02.07.22270514; this version posted February 8, 2022. The copyright holder for this preprint (which was not certified by peer review) is the author/funder, who has granted medRxiv a license to display the preprint in perpetuity.

Gastric Dysfunction in NVS

All rights reserved. No reuse allowed without permission.

The aim of this study is to present a novel medical device and clinical procedure for non-invasive BSGM (Gastric Alimetry ${ }^{\circledR}$; Alimetry, New Zealand), and the results of its first application in patients with NVS.

\section{Methods}

This was a case-control study conducted in Auckland, New Zealand, and Calgary, Canada. Ethical approvals were given by The Auckland Health Research Ethics Committee (AHREC; AH1130) and Conjoint Health Research Ethics Board (CHREB; REB19-1925). All patients provided informed consent. The study is reported in accordance with the STROBE Statement. ${ }^{28}$

\section{$\underline{\text { Participants }}$}

Patients aged $\geq 18$ years with a clinical diagnosis of CNVS (Rome IV Criteria ${ }^{29}$ ) or gastroparesis were eligible. Patients were evaluated and recruited by gastroenterologists, and all were tested to rule out alternative causes for symptoms. Testing included endoscopy and scintigraphic gastric emptying. Exclusion criteria were metabolic, neurogenic, or endocrine disorders known to cause gastric dysmotility other than diabetes (e.g., scleroderma, multiple sclerosis, hyperthyroidism), an active gastrointestinal infection (including H. pylori), inflammatory bowel disease, previous gastric or esophageal surgery, history of gastrointestinal malignancy, or current pregnancy. Patients with cyclical vomiting syndrome or cannabinoid hyperemesis were excluded. Patients were matched to a database of controls (115 subjects $\geq 18$ years recruited by local advertisement during 2021) in a 1:1 ratio using the nearest neighbor method based on age, sex, and BMI, using the matchit package. ${ }^{30}$ Controls were excluded if they had active gastrointestinal symptoms or diseases, and used medications affecting gastric motility or regular cannabis. Specific exclusion criteria related to BSGM (Gastric Alimetry) were BMI >35, active abdominal wounds or abrasions, fragile skin, and allergies to adhesives.

\section{Gastric Alimetry Protocol}


medRxiv preprint doi: https://doi.org/10.1101/2022.02.07.22270514; this version posted February 8, 2022. The copyright holder for this preprint (which was not certified by peer review) is the author/funder, who has granted medRxiv a license to display the preprint in perpetuity.

Gastric Dysfunction in NVS

All rights reserved. No reuse allowed without permission.

Details of the Gastric Alimetry System are reported in the Supplementary Methods and Fig. 1. This system has been comprehensively validated to specifically detect gastric myoelectrical activity, ${ }^{26,27}$ and also registers gastric contractile activity through an increase in signal power. ${ }^{31}$ The standard Gastric Alimetry test protocol was followed (Fig. 1A). Participants were fasted for $>6$ hrs and avoided caffeine and nicotine prior to testing. Medications known to influence gastrointestinal motility were withheld $72 \mathrm{hrs}$ prior, including opiates and prokinetics. Array placement was preceded by skin preparation (NuPrep; Weaver \& Co, CO, USA). Recordings were performed for a fasting period of 30 minutes, followed by a $482 \mathrm{kCal}$ meal consumed over 10 minutes, followed by a 4-hr postprandial recording. The meal consisted of Ensure (232 kcal, $250 \mathrm{~mL}$; Abbott Nutrition, IL, USA) and an oatmeal energy bar (250 kcal, $5 \mathrm{~g}$ fat, $45 \mathrm{~g}$ carbohydrate, $10 \mathrm{~g}$ protein, $7 \mathrm{~g}$ fiber; Clif Bar \& Company, CA, USA). Participants sat reclined in a chair and were asked to limit movement, talking, and sleeping, but were able to read, watch media, work on a mobile device, and mobilize for comfort breaks.

Data analytics encompassed spectral and spatial BSGM variables as described in the

Supplementary Methods, and summarized in Fig. 1. As BSGM is a new test and reference ranges are still being developed, spectral data were classified by consensus panel (four expert assessors) as being normal, abnormal, or indeterminate (when no consensus reached), who were blinded to the group, with reference to established literature (refer Supplementary Methods and Fig. S1).

\section{Patient reported outcomes}

Baseline symptom severity and quality of life were measured using the validated Patient Assessment of Upper Gastrointestinal Disorders-Symptom Severity Index (PAGI-SYM), Gastroparesis Cardinal Symptom Index (GCSI), and Patient Assessment of Upper Gastrointestinal Disorders-Quality of Life (PAGI-QOL) instruments. ${ }^{32,33}$ Symptoms of nausea, bloating, upper gut pain, heartburn, stomach burn, and excessive fullness were measured during testing via the validated Gastric Alimetry App at 15-minute intervals using $0-10$ visual analog scales ( 0 indicating no symptoms; 10 indicating the worst imaginable extent of symptoms). ${ }^{34}$ This data was used to calculate the 'Total Symptom Burden Score' ${ }^{34}$ Early satiation was measured after the meal. Vomiting, reflux, or belching events were also recorded and assessed by frequency. Health psychology metrics included the State Trait Anxiety Inventory Short Form (STAI-SF) and Patient Health Questionnaire-2 (PHQ-2) questionnaires. ${ }^{35,36}$ 
medRxiv preprint doi: https://doi.org/10.1101/2022.02.07.22270514; this version posted February 8, 2022. The copyright holder for this preprint (which was not certified by peer review) is the author/funder, who has granted medRxiv a license to display the preprint in

All rights reserved. No reuse allowed without permission.

Gastric Dysfunction in NVS

Gharibans \& Calder et al. 2022.

\section{Sample size and statistical analysis}

Assuming a $5 \%$ abnormal test rate in controls and $10 \%$ drop out, at 0.05 alpha and $90 \%$ power, a minimum of 30 NVS patients were required to detect a $25.8 \%$ difference in the abnormal test rate between NVS patients and controls.

Principal component analysis (PCA) was used to visualize data groupings based on the consensus panel classification (Python v.3.9.7 scikit-learn package). PCA provides a means for representing high-dimensional data in a low-dimensional space while maximally preserving the variance in the data, by finding weighted combinations of variables (i.e., principal components) that are linearly uncorrelated and can be used to transform data to obtain principal component scores. Statistical analyses were performed in R v.4.0.1 (R Foundation for Statistical Computing, Vienna, Austria). Data were expressed as mean \pm SD, or SEM, or median (IQR). Student's t-test or one-way ANOVA was used for normally distributed data and Mann-Whitney $U$ or Kruskal-Wallis for non-normally distributed data. Post-hoc testing of ANOVA with Tukey correction was performed in subgroup analyses.

Pearson correlations with Hochberg corrections for multiple testing were used to generate correlation matrices for wheel plots. ${ }^{37}$ 
medRxiv preprint doi: https://doi.org/10.1101/2022.02.07.22270514; this version posted February 8, 2022. The copyright holder for this preprint (which was not certified by peer review) is the author/funder, who has granted medRxiv a license to display the preprint in perpetuity.

Gastric Dysfunction in NVS

All rights reserved. No reuse allowed without permission.

\section{Results}

Forty-three consecutively recruited NVS patients were matched to 43 controls. Table S1 presents population demographics, past medical history, and medications. Overall 66/86 (76.7\%) participants were female, median age was 33 (IQR 26 - 44), and mean BMI was 24.3 (SD 4.3). Among patients, 22 were diagnosed with gastroparesis. Patient-reported outcomes are reported in Table S1, and BSGM technical details in Tables S2 and S4. BSGM was successful in all controls and 42/43 patients, with one excluded due to excessive motion artifacts ( $>65 \%$ of test duration).

\section{Whole cohort analysis}

NVS patients demonstrated multiple BSGM abnormalities compared to controls (Fig. S2), including impaired meal responses, characterized by attenuated average postprandial amplitudes (median 23.3 $\mu \mathrm{V}$ (IQR 18.5-31.3) vs $38.0 \mu \mathrm{V}$ (IQR 23.9-63.2); p<0.001) and reduced fed-to-fasting power ratio (median 1.11 (IQR 0.95-1.54) vs 1.59 (IQR 1.1-2.0); $\mathrm{p}=0.02$ ). Average dominant frequencies were normal in both groups (mean NVS $2.69 \mathrm{cpm}$ (SD 0.43); controls $2.88 \mathrm{cpm}$ (SD 0.36)), but patients showed greater variance (0.69 (SD 0.29) vs 0.48 (SD (0.26); $\mathrm{p}<0.001)$. Spatial biomarkers revealed relatively unstable myoelectrical activity in NVS, with reduced spatial frequency stability (median 13.6 (IQR 4.5-42.5) vs 49.5 (IQR 19.1-79.0); $p<0.001)$, and reduced average spatial covariance (0.49 (SD $0.06)$ vs 0.53 (SD 0.06); $p=0.002$ ).

\section{Phenotypes within NVS cohort}

Although the whole cohort analysis revealed strong differences between patients and controls, patient data were heterogeneous (Fig. S2). Two dominant patient subgroups were identified based on normal vs abnormal BSGM tests, which were evaluated with respect to the consensus panel classifications (Fig. 2, S1, S3). Among controls, 41 (95\%) were classified as having normal spectral patterns (Fig. 2A, S3A) (including normal variants - refer Supplementary Methods, Figs S1, S4), one was indeterminate, and one control was classified as abnormal. Among NVS patients, 26 had normal spectral patterns (62\%) (Fig. 2B; Fig S3B), which included 3 patients with isolated high stable frequencies or only transient instabilities (Fig. S4). Thirteen had abnormal spectral patterns (31\%), characterized by absent meal responses, weak or inconsistent dominant frequency bands, and unstable slow-wave rhythm (Fig. 2C; Fig. S3C). Four NVS patients were classified as indeterminate. 
medRxiv preprint doi: https://doi.org/10.1101/2022.02.07.22270514; this version posted February 8, 2022. The copyright holder for this preprint (which was not certified by peer review) is the author/funder, who has granted medRxiv a license to display the preprint in perpetuity.

Gastric Dysfunction in NVS

All rights reserved. No reuse allowed without permission.

Gharibans \& Calder et al. 2022.

Subgroup comparisons were performed between patients with normal BSGM spectral patterns ("NVSN") vs abnormal patterns ("NVS-Abn"). Symptom profiles and quality of life data were comparable between subgroups ( $p>0.1$ for all symptoms and patient-reported outcomes; Fig. 3, Table S2). However, NVS-N patients had substantially higher rates of clinically-diagnosed anxiety and/or depression ( $44.0 \%$ vs $7.7 \%$; $p=0.03$ ), were more likely to be on anxiolytic or antidepressant / neuromodulator prescriptions ( $50.0 \%$ vs $15.4 \% ; p=0.045)$, and had higher state anxiety scores (median 16.5; IQR 14-21 vs 13; IQR 10-16; p=0.035) (Fig. 3). NVS-Abn showed statistically different spectral and spatial BSGM metrics compared to NVS-N patients, with higher standard deviation of the dominant frequency $(p=0.04)$, a lower percentage of the recording in normal gastric frequency $(31 \%$ vs $76 \%, p=0.04$ ), and reduced spatial frequency stability ( $p=0.004$ ) (Fig. 3 ). In comparison to the control cohort, the NVS-Abn group had significantly impaired spectral and spatial metrics $(p<0.02)$, whereas all metrics were comparable to controls in NVS-N patients ( $p>0.05)$ (Table S2, Fig. 3). Delayed gastric emptying status by subgroup is reported in Table S4.

PCA enabled visual confirmation of group differences as a function of weighted metric combinations. A combination of BSGM, psychological questionnaires, and symptom metrics clearly separated controls, NVS-N and NVS-Abn groups (Fig. 4). PCA using only BSGM test metrics separated NVSAbn patients from NVS-N patients and controls, whereas conducting PCA using only psychological questionnaires and symptom metrics separated patients and controls, but did not separate NVS-N and NVS-Abn patients (Figs. S5 and S6).

\section{Symptom Correlations}

Symptom correlations were performed between the NVS-N and NVS-Abn subgroups and controls. In the NVS-N group, anxiety and depression metrics correlated with symptom severity $(r>35 ; p<0.05$;

Fig. 3 and Fig. 5A), whereas BSGM metrics did not correlate ( $p>0.4)$. In the NVS-Abn group, BSGM metrics correlated with the severity of symptoms (including nausea, pain, excessive fullness, early satiety, bloating, heartburn and GCSI score; all $r>0.35, p<0.05$ ), whereas anxiety and depression metrics did not correlate ( $p>0.1$ ) (Fig. 3 and Fig. 5B). In the NVS-Abn group, the $\%$ duration in the 
medRxiv preprint doi: https://doi.org/10.1101/2022.02.07.22270514; this version posted February 8, 2022. The copyright holder for this preprint (which was not certified by peer review) is the author/funder, who has granted medRxiv a license to display the preprint in

All rights reserved. No reuse allowed without permission.

Gastric Dysfunction in NVS

Gharibans \& Calder et al. 2022.

normal frequency range was strongly correlated with mean GCSI $(r=-0.58 ; p<0.001)$ and PAGI-SYM $(r=-0.59 ; p<0.001)$,

\section{Safety}

No participants experienced a serious adverse event. Mild transient side effects included rash $(n=12)$

and itch $(n=8)$, with one patient requiring topical therapy. The test was well tolerated overall, evidenced by patients being highly likely to recommend the test to other patients when asked on a scale of 0 to 10 (median 9; IQR 8-10). 
medRxiv preprint doi: https://doi.org/10.1101/2022.02.07.22270514; this version posted February 8, 2022. The copyright holder for this preprint (which was not certified by peer review) is the author/funder, who has granted medRxiv a license to display the preprint in

All rights reserved. No reuse allowed without permission.

Gastric Dysfunction in NVS

\section{Discussion}

This study introduced a new medical device and test for non-invasively characterizing gastric myoelectrical activity using BSGM, and applied it to NVS. Multiple abnormalities were revealed including weak, irregular and unstable gastric myoelectrical activity and impaired meal responses. These abnormalities were confined to a subgroup (31\%), with $62 \%$ of patients demonstrating normal tests, as confirmed by group-wise statistics, PCA, and symptom correlations via linear regression analysis. These data indicate that NVS likely comprises distinct underlying phenotypes that can be differentiated by BSGM.

Gastric neuromuscular pathology and dysregulation of brain-gut interaction have emerged as dominant putative mechanisms of NVS. ${ }^{15,19,38}$ Our findings are consistent with both mechanisms, but suggest that each may be responsible for a separate phenotype; a distinction not previously possible because of overlapping symptom profiles. Although ICC or immune cell counts were not measured in this non-invasive study, it is likely that the BSGM abnormalities observed are the electrophysiological correlate of underlying neuromuscular disease. Multiple studies have identified ICC network depletion as a pathological hallmark of both gastroparesis, and more recently CNVS, associated with a macrophage-driven immune dysregulation. ${ }^{11,16-19}$ ICC loss leads to slow-wave irregularities and contractile dysfunction, ${ }^{16,17,20}$ which is consistent with our data showing weak, irregular and unstable gastric myoelectrical activity and impaired meal responses. Benchmark studies have shown that ICC depletion is restricted to $\sim 50 \%$ of NVS patients, with the remainder showing normal ICC counts, ${ }^{16,19}$ approximating our two subgroups. As evaluating myenteric ICC currently requires highly-invasive fullthickness gastric biopsies, the development of BSGM as a non-invasive tool for the routine clinical assessment of gastric motility could represent a valuable clinical advance.

The subgroup with normal BSGM tests were significantly more likely to have a clinical diagnosis of anxiety and depression and had higher anxiety state scores, consistent with dysregulated brain-gut interaction. ${ }^{15}$ Brain-gut symptom genesis is well established, including in NVS, ${ }^{39}$ such that it has been proposed to rename functional gastrointestinal disorders to disorders of brain-gut interaction. ${ }^{15}$ However, neither descriptor appears adequate in this context, because of the subgroup with organic neuromuscular disease. ${ }^{11,16}$ In addition, approximately half of the patients with normal BSGM tests in 
medRxiv preprint doi: https://doi.org/10.1101/2022.02.07.22270514; this version posted February 8, 2022. The copyright holder for this preprint (which was not certified by peer review) is the author/funder, who has granted medRxiv a license to display the preprint in perpetuity.

Gastric Dysfunction in NVS

All rights reserved. No reuse allowed without permission.

our study showed no psychological comorbidities, and there are other mechanisms (e.g. diabetic neuropathy) to account for the heterogeneity of NVS. ${ }^{40}$ With further validation, BSGM could support the evolution of NVS nomenclature toward more specific disease subtypes, which in turn should improve clinical decision making (e.g. selection of targeted treatments) and allow more homogenous allocation into research trials.

Patients with NVS have previously been divided into those with gastroparesis or CNVS based on the presence or absence of delayed gastric emptying. However, this division is increasingly tenuous, given that epidemiology, symptom profiles, and quality of life impacts are comparable, and that gastric emptying may not be a primary disease mechanism. ${ }^{6,711,41}$ Moreover, Pasricha et al recently demonstrated that gastric emptying rates are labile over time, with $>40 \%$ of patients switching disease categories within one year. In view of this poor specificity, NVS patients were considered here as a common group. To determine how BSGM and gastric emptying testing compare, it will be necessary to perform the two tests simultaneously.

Alvarez introduced EGG 100 years ago in a seminal paper in JAMA, ${ }^{42}$ and multiple EGG studies have demonstrated aberrant gastric myoelectrical activity in $>50 \%$ of NVS patients, predominantly based on frequency endpoints. ${ }^{13}$ However, clinical adoption of EGG has not followed because it has generally been considered unreliable for investigating individual patients or guiding management, partly related to difficulties in interpreting the signals. ${ }^{43}$ BSGM by Gastric Alimetry represents a critical advance over EGG, enabled by multiple technical improvements including modern bioamplifiers, HR flexible electronics, validated signal processing algorithms for automated noise reduction, and a patient-specific electrode positioning guide to address anatomical variation. ${ }^{22,27,44}$ Four hour standard post-prandial recordings were also introduced, because we found that meal responses in controls show variable time courses that could confound matched comparisons. ${ }^{27}$ In addition, new endpoint criteria were established, including a number of novel biomarkers such as spatial parameters, after previously determining that frequency alone is insufficient to characterize gastric abnormalities. ${ }^{17,22,27,45}$ Taken together, these improvements yielded sufficient discriminative power to clearly distinguish a subgroup of patients with gastric dysfunction amongst NVS patients by multiple statistical methods and at the individual subject level. 
medRxiv preprint doi: https://doi.org/10.1101/2022.02.07.22270514; this version posted February 8, 2022. The copyright holder for this preprint (which was not certified by peer review) is the author/funder, who has granted medRxiv a license to display the preprint in

All rights reserved. No reuse allowed without permission.

Gastric Dysfunction in NVS

Gharibans \& Calder et al. 2022.

Our results with a medical device improve upon earlier reports using BSGM research prototypes. ${ }^{24,25}$ Gharibans et al studied a mixed cohort including functional dyspepsia, and reported that abnormal slow-wave direction correlated with symptoms. ${ }^{24}$ For NVS, we focused primarily on slow-wave stability and meal response metrics, because our previous invasive HR mapping studies documented slowwave irregularities in association with ICC depletion. ${ }^{16,17}$ However, it would now be valuable to comprehensively study functional dyspepsia for comparison. Somarajan et al applied a prototype BSGM system in a cohort of children with NVS, finding aberrant frequencies and spatial patterns ${ }^{25}$ indicating that Gastric Alimetry will also be an applicable non-invasive tool in pediatric populations. ${ }^{46}$

Several limitations are acknowledged. Although specific criteria were employed, using a consensus panel classification introduces subjectivity that could limit reproducibility. BSGM reference ranges are therefore being established to promote standardized reporting. Classifications were conservative, being based primarily on meal responses and gastric rhythm, and patients with borderline tests (e.g. isolated high stable frequencies and transient abnormalities) were currently classed as negative. As more data becomes available, it will be possible to refine the classification scheme, and together with emerging spatial metrics, ${ }^{26,47}$ this should increase discriminative power.

In summary, this study introduces a novel medical device for BSGM and demonstrates its utility in a study of NVS patients who share common symptom profiles but reveal distinct phenotypes. These findings could improve clinical management of NVS patients by separating those with gastric dysfunction from those with gut-brain dysregulation or other aetiologies. 
medRxiv preprint doi: https://doi.org/10.1101/2022.02.07.22270514; this version posted February 8, 2022. The copyright holder for this preprint (which was not certified by peer review) is the author/funder, who has granted medRxiv a license to display the preprint in

perpetuity.
All rights reserved. No reuse allowed without permission.

Gastric Dysfunction in NVS

Gharibans \& Calder et al. 2022.

\section{Conflicts of Interest}

GOG, PD and AG hold grants and intellectual property in the field of gastrointestinal electrophysiology. GOG and AG are founders and Directors of Alimetry Ltd. GOG is Director in The Insides Company. SC, SW, CD, GS, PD, JW and CNA are members of Alimetry Ltd. PD is a Director in FlexiMap Ltd. The remaining authors have no conflicts of interest to declare.

\section{Funding}

This work was supported by the Health Research Council of New Zealand, Royal Society Te Apārangi, and the John Mitchell Crouch Fellowship from the Royal Australasian College of Surgeons.

\section{Acknowledgements}

We thank Gen Johnson, India Wallace, Sonia Binden, Lynn Wilsack, and Renata Rehak for their outstanding assistance with participant recruitment, and to all of our study participants for enabling this work. 
medRxiv preprint doi: https://doi.org/10.1101/2022.02.07.22270514; this version posted February 8, 2022. The copyright holder for this preprint (which was not certified by peer review) is the author/funder, who has granted medRxiv a license to display the preprint in perpetuity.

Gastric Dysfunction in NVS

All rights reserved. No reuse allowed without permission.

\section{References}

1. Sperber, A. D. et al. Worldwide Prevalence and Burden of Functional Gastrointestinal Disorders, Results of Rome Foundation Global Study. Gastroenterology 160, 99-114.e3 (2021).

2. Ye, Y. et al. Epidemiology and outcomes of gastroparesis, as documented in general practice records, in the United Kingdom. Gut 70, 644-653 (2021).

3. Aziz, I. et al. Epidemiology, Clinical Characteristics, and Associations for Rome IV Functional Nausea and Vomiting Disorders in Adults. Clin. Gastroenterol. Hepatol. 17, 878-886 (2019).

4. Jung, H.-K. et al. Chronic unexplained nausea in adults: Prevalence, impact on quality of life, and underlying organic diseases in a cohort of 5096 subjects comprehensively investigated. PLoS One 14, e0225364 (2019).

5. Wang, Y. R., Fisher, R. S. \& Parkman, H. P. Gastroparesis-related hospitalizations in the United States: trends, characteristics, and outcomes, 1995-2004. Am. J. Gastroenterol. 103, 313-322 (2008).

6. Pasricha, P. J. et al. Characteristics of patients with chronic unexplained nausea and vomiting and normal gastric emptying. Clin. Gastroenterol. Hepatol. 9, 567-76.e1-4 (2011).

7. Harer, K. N. \& Pasricha, P. J. Chronic Unexplained Nausea and Vomiting or Gastric Neuromuscular Dysfunction (GND)? An Update on Nomenclature, Pathophysiology and Treatment, and Relationship to Gastroparesis. Current Treatment Options in Gastroenterology vol. 14 410-419 (2016).

8. Vijayvargiya, P. et al. Association between delayed gastric emptying and upper gastrointestinal symptoms: a systematic review and meta-analysis. Gut 68, 804-813 (2019).

9. Janssen, P. et al. The relation between symptom improvement and gastric emptying in the treatment of diabetic and idiopathic gastroparesis. Am. J. Gastroenterol. 108, 1382-1391 (2013).

10. Bharucha, A. E., Camilleri, M., Forstrom, L. A. \& Zinsmeister, A. R. Relationship between clinical features and gastric emptying disturbances in diabetes mellitus. Clin. Endocrinol. 70, 415-420 (2009).

11. Pasricha, P. J. et al. Functional Dyspepsia and Gastroparesis in Tertiary Care are Interchangeable Syndromes With Common Clinical and Pathologic Features. Gastroenterology 160, 2006-2017 (2021).

12. Tack, J., Schol, J. \& Horowitz, M. Gastroparesis: A Dead-end Street After All? Gastroenterology vol. 160 1931-1933 (2021).

13. Carson, D. A. et al. Abnormalities on Electrogastrography in Nausea and Vomiting Syndromes: A Systematic Review, Meta-Analysis, and Comparison to Other Gastric Disorders. Dig. Dis. Sci. (2021) doi:10.1007/s10620-021-07026-x.

14. Vosoughi, K. et al. Gastric per-oral endoscopic myotomy (G-POEM) for refractory gastroparesis: results from an international prospective trial. Gut 71, 25-33 (2022).

15. Black, C. J., Drossman, D. A., Talley, N. J., Ruddy, J. \& Ford, A. C. Functional gastrointestinal disorders: 
medRxiv preprint doi: https://doi.org/10.1101/2022.02.07.22270514; this version posted February 8, 2022. The copyright holder for this preprint (which was not certified by peer review) is the author/funder, who has granted medRxiv a license to display the preprint in perpetuity.

Gastric Dysfunction in NVS

All rights reserved. No reuse allowed without permission.

advances in understanding and management. Lancet 396, 1664-1674 (2020).

16. Angeli, T. R. et al. Loss of Interstitial Cells of Cajal and Patterns of Gastric Dysrhythmia in Patients With Chronic Unexplained Nausea and Vomiting. Gastroenterology 149, 56-66.e5 (2015).

17. O'Grady, G. et al. Abnormal initiation and conduction of slow-wave activity in gastroparesis, defined by highresolution electrical mapping. Gastroenterology 143, (2012).

18. Grover, M. et al. Clinical-histological associations in gastroparesis: results from the Gastroparesis Clinical Research Consortium. Neurogastroenterol. Motil. 24, 531-9, e249 (2012).

19. Grover, M. et al. Cellular changes in diabetic and idiopathic gastroparesis. Gastroenterology 140, 157585.e8 (2011).

20. O'Grady, G., Gharibans, A. A., Du, P. \& Huizinga, J. D. The gastric conduction system in health and disease: a translational review. Am. J. Physiol. Gastrointest. Liver Physiol. 321, G527-G542 (2021).

21. Lin, Z. et al. Association of the status of interstitial cells of Cajal and electrogastrogram parameters, gastric emptying and symptoms in patients with gastroparesis. Neurogastroenterol. Motil. 22, 56-61, e10 (2010).

22. Carson, D. A., O'Grady, G., Du, P., Gharibans, A. A. \& Andrews, C. N. Body surface mapping of the stomach: New directions for clinically evaluating gastric electrical activity. Neurogastroenterology \& Motility 150, 1380-1392 (2020).

23. Bortolotti, M. Electrogastrography: a seductive promise, only partially kept. The American journal of gastroenterology vol. 93 1791-1794 (1998).

24. Gharibans, A. A., Coleman, T. P., Mousa, H. \& Kunkel, D. C. Spatial Patterns From High-Resolution Electrogastrography Correlate With Severity of Symptoms in Patients With Functional Dyspepsia and Gastroparesis. Clin. Gastroenterol. Hepatol. 17, 2668-2677 (2019).

25. Somarajan, S. et al. The effect of chronic nausea on gastric slow wave spatiotemporal dynamics in children. Neurogastroenterol. Motil. 33, e14035 (2021).

26. Calder, S. et al. Validation of non-invasive body-surface gastric mapping for detecting electrophysiological biomarkers by simultaneous high-resolution serosal mapping in a porcine model. doi:10.1101/2021.08.01.454685.

27. Gharibans, A. et al. A novel scalable electrode array and system for non-invasively assessing gastric function using flexible electronics. Research Square (2022) doi:10.21203/rs.3.rs-1233270/v1.

28. Vandenbroucke, J. P. et al. Strengthening the Reporting of Observational Studies in Epidemiology (STROBE): explanation and elaboration. PLoS Med. 4, e297 (2007).

29. Stanghellini, V. et al. Gastroduodenal Disorders. Gastroenterology 150, 1380-1392 (2016).

30. Ho, D. E., Imai, K., King, G. \& Stuart, E. A. Matchlt: Nonparametric Preprocessing for Parametric Causal Inference. Journal of Statistical Software vol. 42 1-28 (2011).

31. Smout, A. J., van der Schee, E. J. \& Grashuis, J. L. What is measured in electrogastrography? Dig. Dis. Sci. 
medRxiv preprint doi: https://doi.org/10.1101/2022.02.07.22270514; this version posted February 8, 2022. The copyright holder for this preprint (which was not certified by peer review) is the author/funder, who has granted medRxiv a license to display the preprint in perpetuity.

Gastric Dysfunction in NVS

All rights reserved. No reuse allowed without permission.

25, 179-187 (1980).

32. Rentz, A. M. et al. Development and psychometric evaluation of the patient assessment of upper gastrointestinal symptom severity index (PAGI-SYM) in patients with upper gastrointestinal disorders. Qual. Life Res. 13, 1737-1749 (2004).

33. De la loge, C. et al. Cross-cultural development and validation of a patient self-administered questionnaire to assess quality of life in upper gastrointestinal disorders: The PAGI-QOLC. Qual. Life Res. 13, 1751-1762 (2004).

34. Sebaratnam, G. et al. A standardized system and App for continuous patient symptom logging in gastroduodenal disorders: design, implementation, and validation. bioRxiv (2021) doi:10.1101/2021.09.06.21263001.

35. Spielberger, C. D. State-Trait Anxiety Inventory. The Corsini Encyclopedia of Psychology (2010) doi:10.1002/9780470479216.corpsy0943.

36. Kroenke, K., Spitzer, R. L. \& Williams, J. B. W. The Patient Health Questionnaire-2: validity of a two-item depression screener. Med. Care 41, 1284-1292 (2003).

37. Hochberg, Y. A sharper Bonferroni procedure for multiple tests of significance. Biometrika vol. 75 800-802 (1988).

38. Grover, M., Farrugia, G. \& Stanghellini, V. Gastroparesis: a turning point in understanding and treatment. Gut 68, 2238-2250 (2019).

39. Woodhouse, S., Hebbard, G. \& Knowles, S. R. Psychological controversies in gastroparesis: A systematic review. World J. Gastroenterol. 23, 1298-1309 (2017).

40. Sanger, G. J. \& Andrews, P. L. R. A History of Drug Discovery for Treatment of Nausea and Vomiting and the Implications for Future Research. Front. Pharmacol. 9, 913 (2018).

41. Schol, J. et al. United European Gastroenterology (UEG) and European Society for Neurogastroenterology and Motility (ESNM) consensus on gastroparesis. Neurogastroenterol. Motil. 33, e14237 (2021).

42. Alvarez, W. C. The electrogastrogram and what it shows. JAMA 78, 1116-1119 (1922).

43. Lacy, B. E. et al. Diagnostic Evaluation of Gastric Motor and Sensory Disorders. Official journal of the American College of Gastroenterology / ACG 116, 2345 (2021).

44. Gharibans, A. A. et al. Artifact Rejection Methodology Enables Continuous, Noninvasive Measurement of Gastric Myoelectric Activity in Ambulatory Subjects. Sci. Rep. 8, 5019 (2018).

45. O'Grady, G. et al. Methods for High-Resolution Electrical Mapping in the Gastrointestinal Tract. IEEE Reviews in Biomedical Engineering vol. 12 287-302 (2019).

46. Bhat, S. et al. Electrogastrography Abnormalities in Pediatric Gastroduodenal Disorders: A Systematic Review and Meta-analysis. J. Pediatr. Gastroenterol. Nutr. 73, 9-16 (2021).

47. Calder, S., O'Grady, G., Cheng, L. K. \& Peng Du. A Theoretical Analysis of Electrogastrography (EGG) 
medRxiv preprint doi: https://doi.org/10.1101/2022.02.07.22270514; this version posted February 8, 2022. The copyright holder for this preprint (which was not certified by peer review) is the author/funder, who has granted medRxiv a license to display the preprint in All rights reserved. No reuse allowed without permission.

Gastric Dysfunction in NVS

Gharibans \& Calder et al. 2022.

Signatures Associated With Gastric Dysrhythmias. IEEE Trans. Biomed. Eng. 64, 1592-1601 (2017).

48. Gharibans, A. A., Coleman, T., Mousa, H. \& Kunkel, D. High-Density Multichannel Electrode Array Improves the Accuracy of Cutaneous Electrogastrography Across Subjects With Wide-Ranging BMI: 1235. Am. J. Gastroenterol. 113, S708 (2018).

49. Calder, S., O'Grady, G., Cheng, L. K. \& Du, P. A Simulated Anatomically Accurate Investigation Into the Effects of Biodiversity on Electrogastrography. IEEE Transactions on Biomedical Engineering vol. 67868 875 (2020).

50. Angeli, T. R. et al. The bioelectrical basis and validity of gastrointestinal extracellular slow wave recordings. J. Physiol. 591, 4567-4579 (2013).

51. Zhu, H. \& Chen, J. D. Z. Gastric distension alters frequency and regularity but not amplitude of the gastric slow wave. Neurogastroenterology and Motility vol. 16 745-752 (2004).

52. Yin, J. \& Chen, J. D. Z. Electrogastrography: Methodology, Validation and Applications. Journal of Neurogastroenterology and Motility vol. 19 5-17 (2013).

53. Koch, K. L. \& Stern, R. M. Handbook of Electrogastrography. (Oxford University Press, 2004). 
medRxiv preprint doi: https://doi.org/10.1101/2022.02.07.22270514; this version posted February 8, 2022. The copyright holder for this preprint (which was not certified by peer review) is the author/funder, who has granted medRxiv a license to display the preprint in perpetuity.

Gastric Dysfunction in NVS

All rights reserved. No reuse allowed without permission.

Gharibans \& Calder et al. 2022.

Figures

Figure 1

A. Body surface gastric mapping pipeline

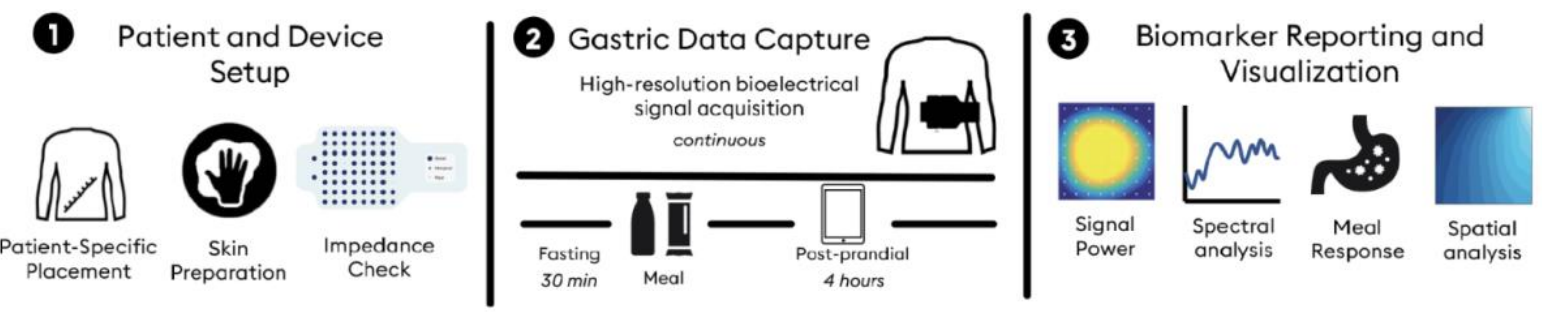

B. Gastric Alimetry System
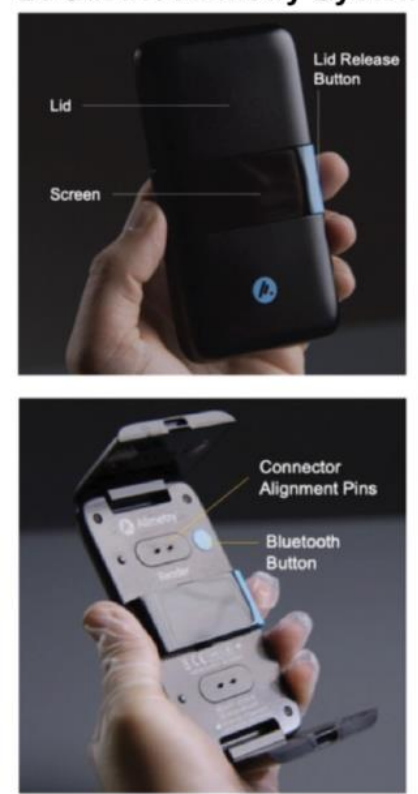

C. Signal strength
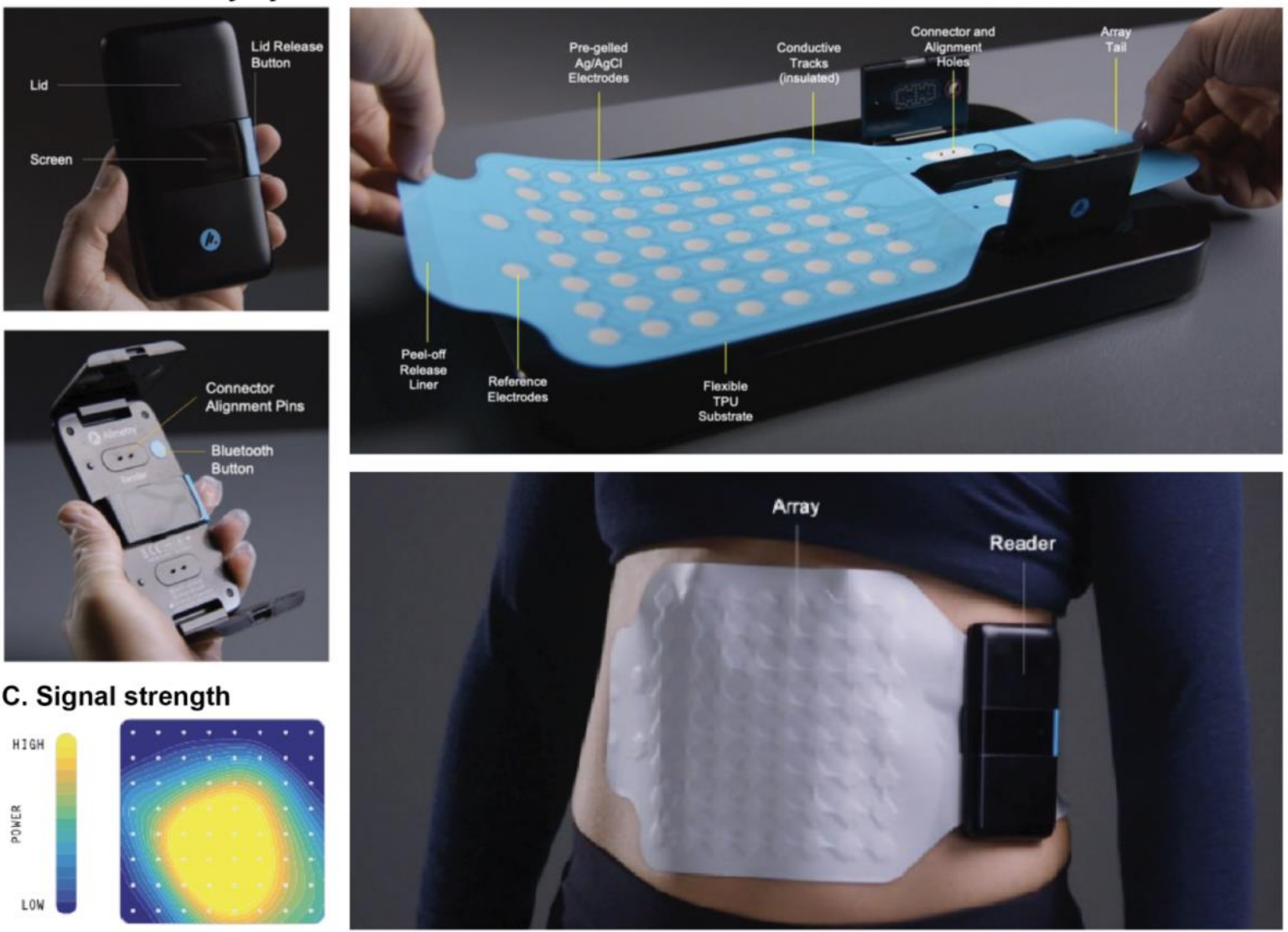

D. Spectral analysis

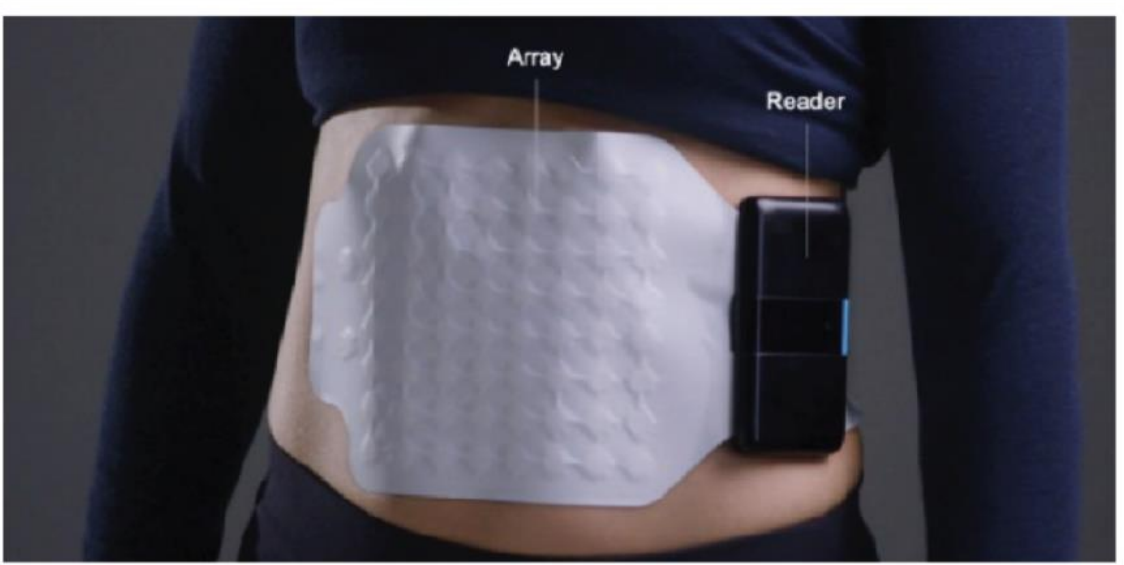

\section{Dominant frequency band}

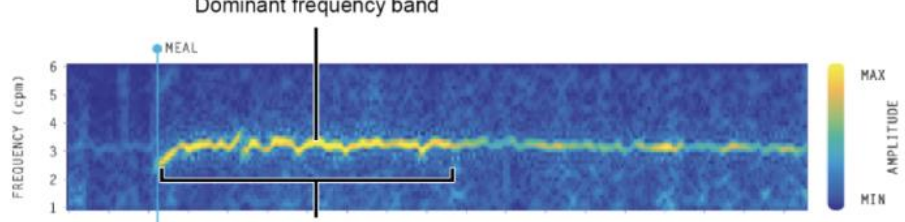

E. Spatial analysis

Spatial frequency stability
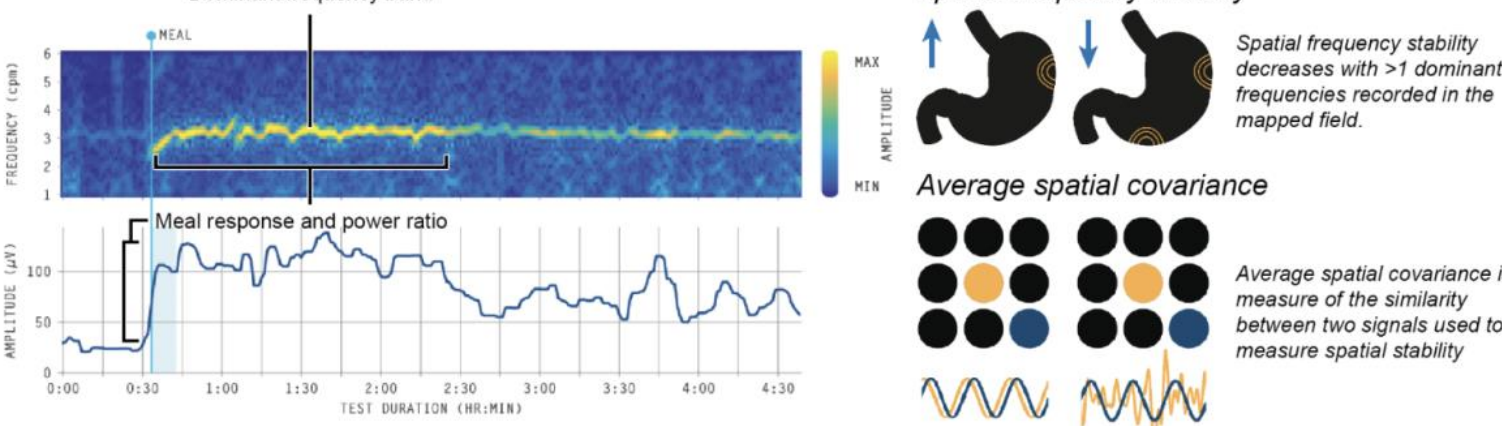

Average spatial covariance

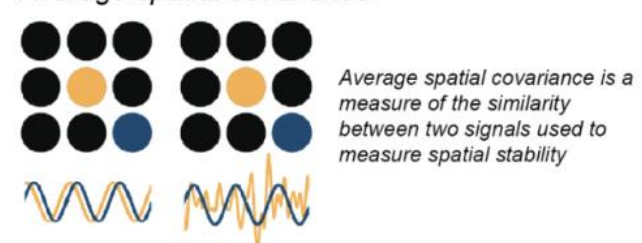

BSGM system and analysis pipeline. A) Outline of standardized BSGM test procedure. ${ }^{27}$ B) The

Gastric Alimetry Device, shown in closed and open profiles, during setup of the high-resolution array 
medRxiv preprint doi: https://doi.org/10.1101/2022.02.07.22270514; this version posted February 8, 2022. The copyright holder for this preprint (which was not certified by peer review) is the author/funder, who has granted medRxiv a license to display the preprint in perpetuity.

All rights reserved. No reuse allowed without permission.

Gastric Dysfunction in NVS

Gharibans \& Calder et al. 2022.

(8x8 pre-gelled $\mathrm{Ag} / \mathrm{AgCl}$ electrodes), and in position overlying the epigastrium. C. Signal strength is visualized on an $8 \times 8$ electrode grid corresponding to the array, with the region of high-power activity corresponding to the gastric position in the mapped field. ${ }^{27}$ D. BSGM analytics employed in this study comprised spectral metrics (meal response, power ratio, rhythm, dominant slow wave frequency; used for test classifications) and spatial metrics (measures of spatial slow wave stability; spatial frequency stability and average spatial covariance). Refer Supplementary Methods for further detail. 
medRxiv preprint doi: https://doi.org/10.1101/2022.02.07.22270514; this version posted February 8, 2022. The copyright holder for this preprint (which was not certified by peer review) is the author/funder, who has granted medRxiv a license to display the preprint in perpetuity.

Gastric Dysfunction in NVS

All rights reserved. No reuse allowed without permission.

Gharibans \& Calder et al. 2022.

\section{Figure 2}

A.

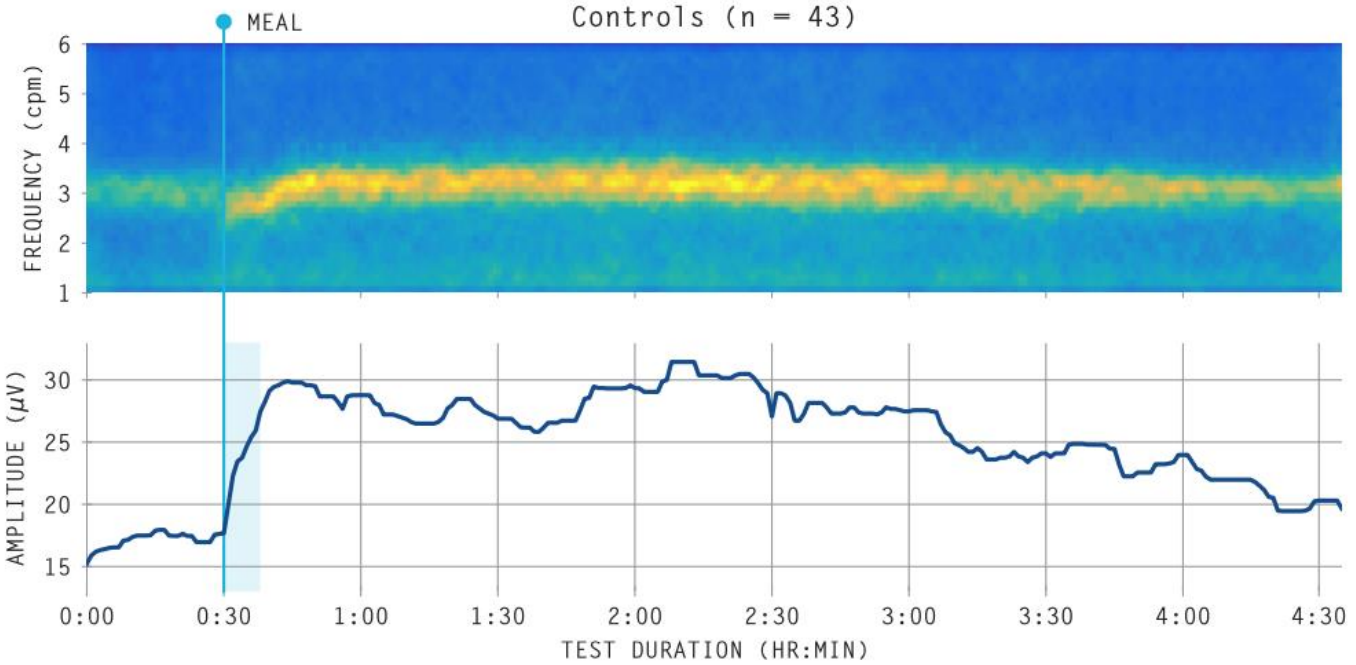

B.

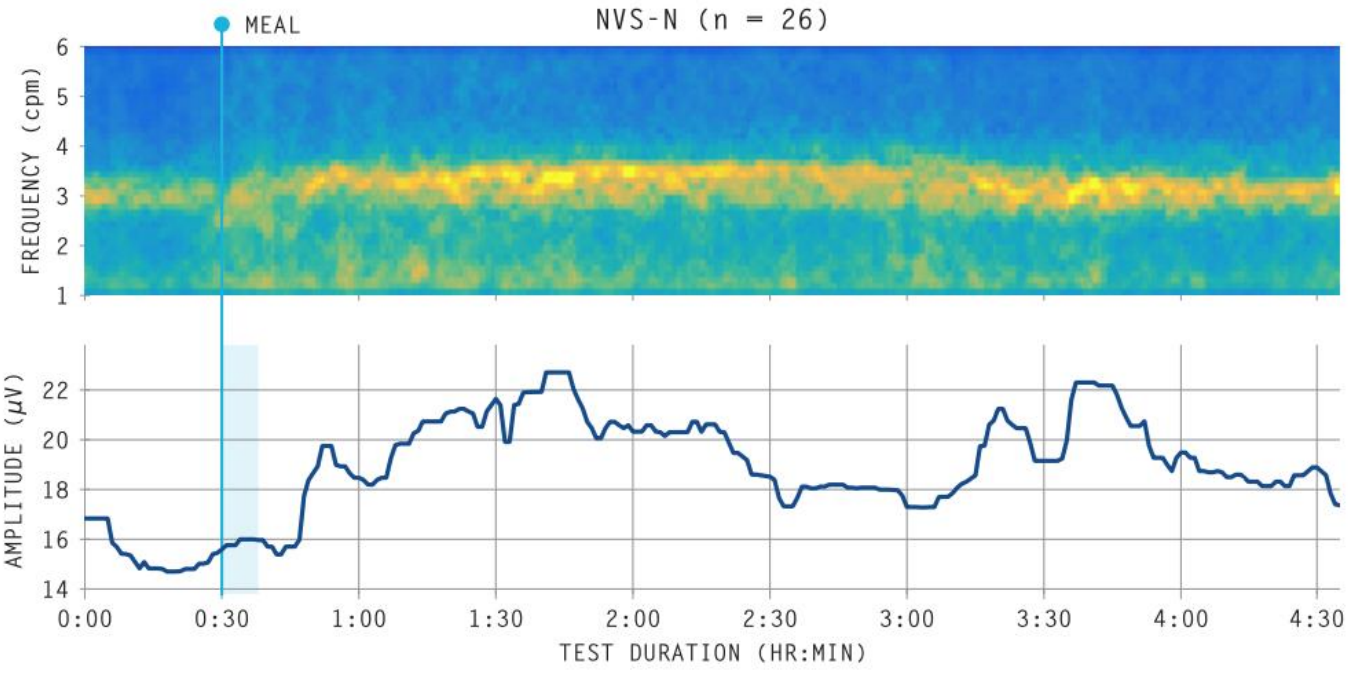

C.

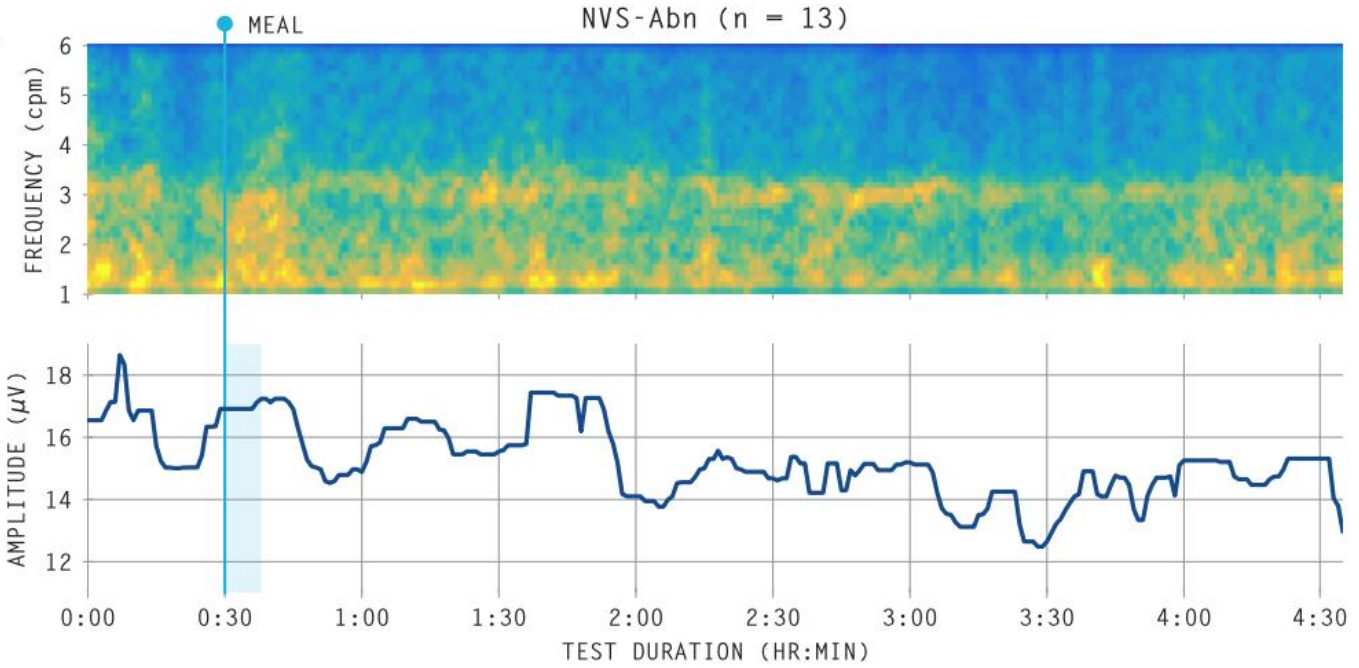

Average BSGM spectral plots (frequency-amplitude graphs), showing dominant frequencies on a scale from low power (dark blue) to high power (bright yellow), indicating gastric meal responses and rhythm, and with amplitude plots beneath, for healthy controls, NVS-N and NVS-Abn groups. The 
medRxiv preprint doi: https://doi.org/10.1101/2022.02.07.22270514; this version posted February 8, 2022. The copyright holder for this preprint (which was not certified by peer review) is the author/funder, who has granted medRxiv a license to display the preprint in perpetuity.
All rights reserved. No reuse allowed without permission.

Gastric Dysfunction in NVS

Gharibans \& Calder et al. 2022.

meal time and duration is indicated by a vertical blue bar at $30 \mathrm{~min}$. Normal spectral plots $(\mathbf{A}, \mathbf{B})$ show a clear meal response (post-prandial power increase), a consistent and sustained frequency band, and a regular gastric rhythm (Supplementary Methods and Fig. S1). C) Abnormal cases lacked these features. Individual subject examples from each category are provided in Fig. S3, and examples of normal and patient variations are provided in Fig. S4. 
medRxiv preprint doi: https://doi.org/10.1101/2022.02.07.22270514; this version posted February 8, 2022. The copyright holder for this preprint (which was not certified by peer review) is the author/funder, who has granted medRxiv a license to display the preprint in perpetuity.

Gastric Dysfunction in NVS

All rights reserved. No reuse allowed without permission.

Gharibans \& Calder et al. 2022.

Figure 3
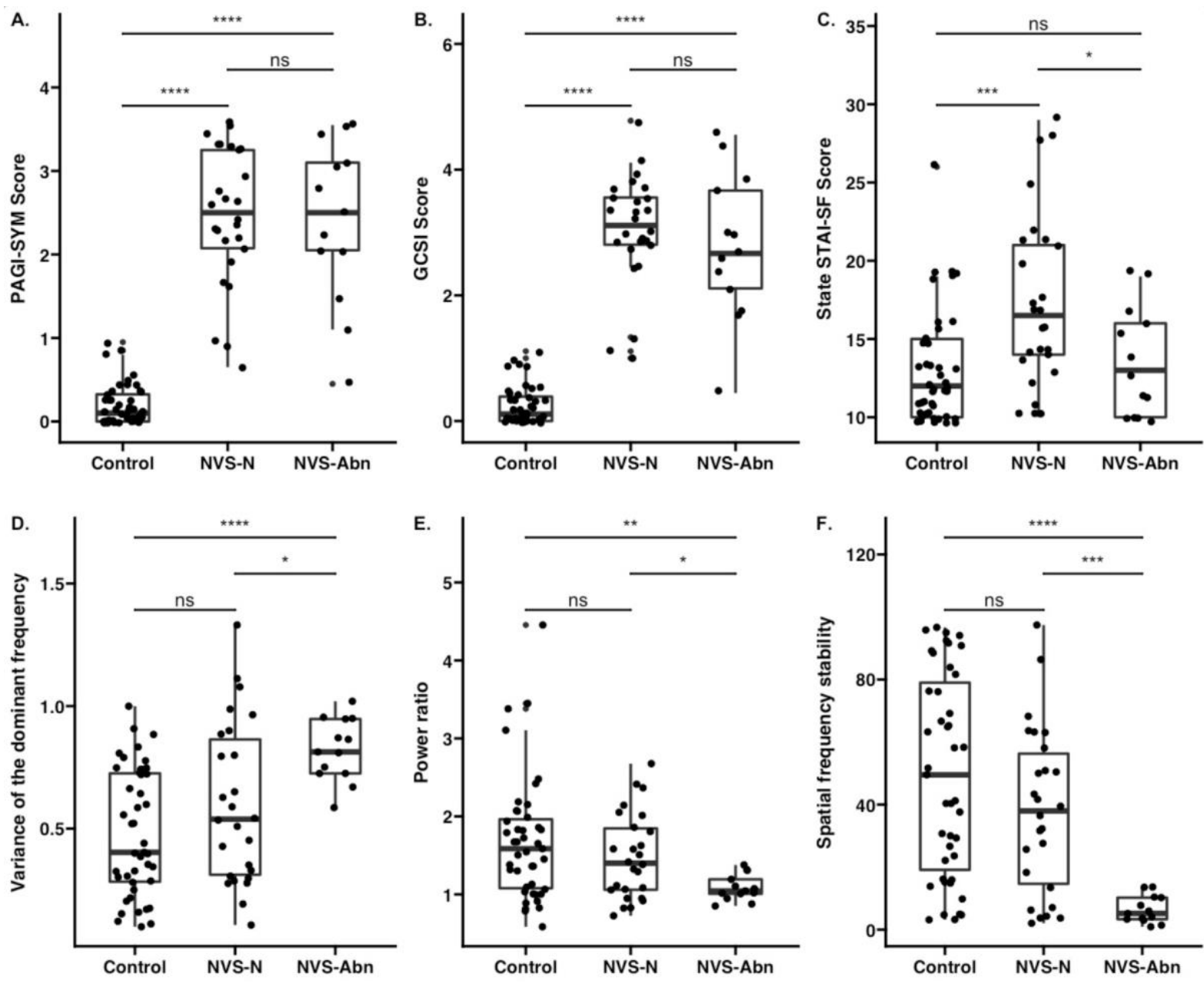

Box plots of symptoms and metrics across controls, and those that had a positive (abnormal) and negative (normal) BSGM test in the NVS cohort. PAGI-SYM, Patient Assessment of Upper Gastrointestinal Disorders-Symptom Severity Index; GCSI, Gastroparesis Cardinal Symptom Index.

STAI-SF; State-Trait Anxiety Inventory Short Form. ns; $p>0.05,{ }^{*} ; p \leq 0.05,{ }^{* *} ; p<0.01,{ }^{* * *} ; p<0.001$, ${ }^{* * * *} ; p<0.0001$. 
medRxiv preprint doi: https://doi.org/10.1101/2022.02.07.22270514; this version posted February 8, 2022. The copyright holder for this preprint (which was not certified by peer review) is the author/funder, who has granted medRxiv a license to display the preprint in perpetuity.

Gastric Dysfunction in NVS

All rights reserved. No reuse allowed without permission.

Gharibans \& Calder et al. 2022.

\section{Figure 4}

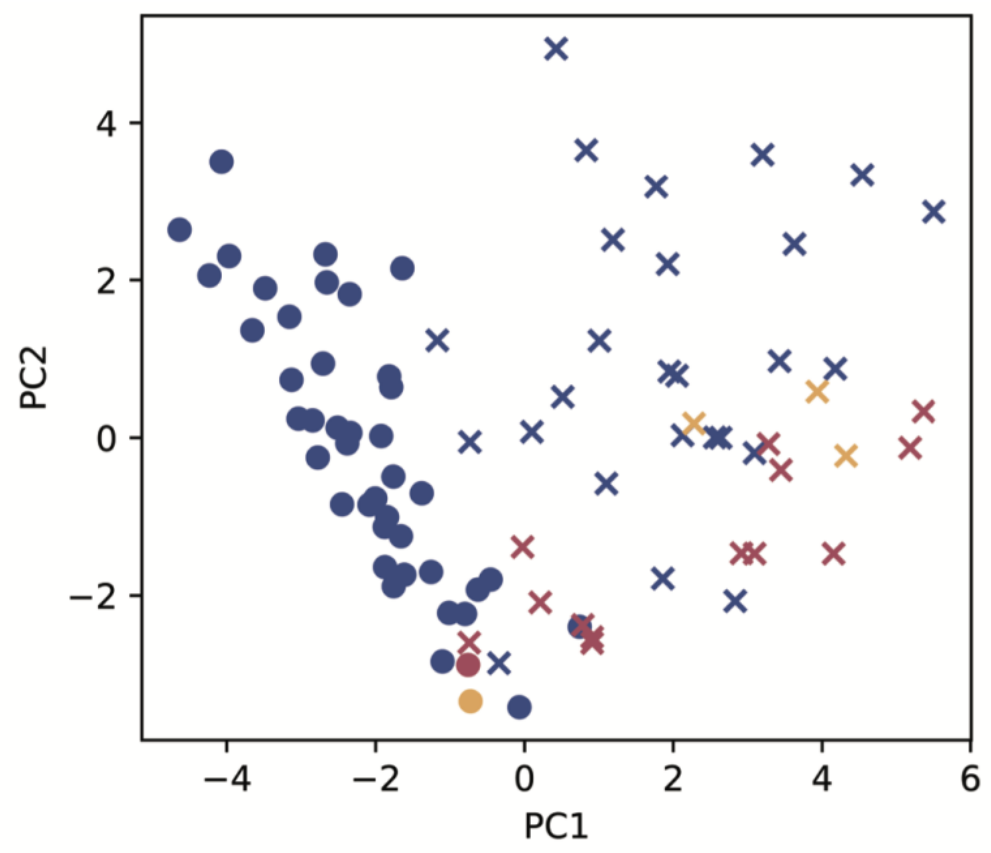

Control: Normal test

Control: Indeterminate

- Control: Abnormal test

$\times$ Patient: Normal test

$\times$ Patient: Indeterminate

$x$ Patient: Abnormal test

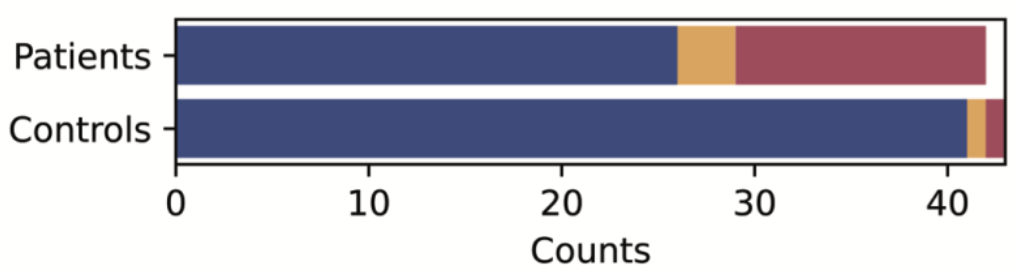

Normal

Indeterminate

Abnormal

Top: Principal component analysis of healthy controls and NVS patients utilizing body surface gastric mapping metrics, symptom scores, and health psychology data. Below: case classifications. 
medRxiv preprint doi: https://doi.org/10.1101/2022.02.07.22270514; this version posted February 8, 2022. The copyright holder for this preprint (which was not certified by peer review) is the author/funder, who has granted medRxiv a license to display the preprint in perpetuity.

\section{Figure 5:}
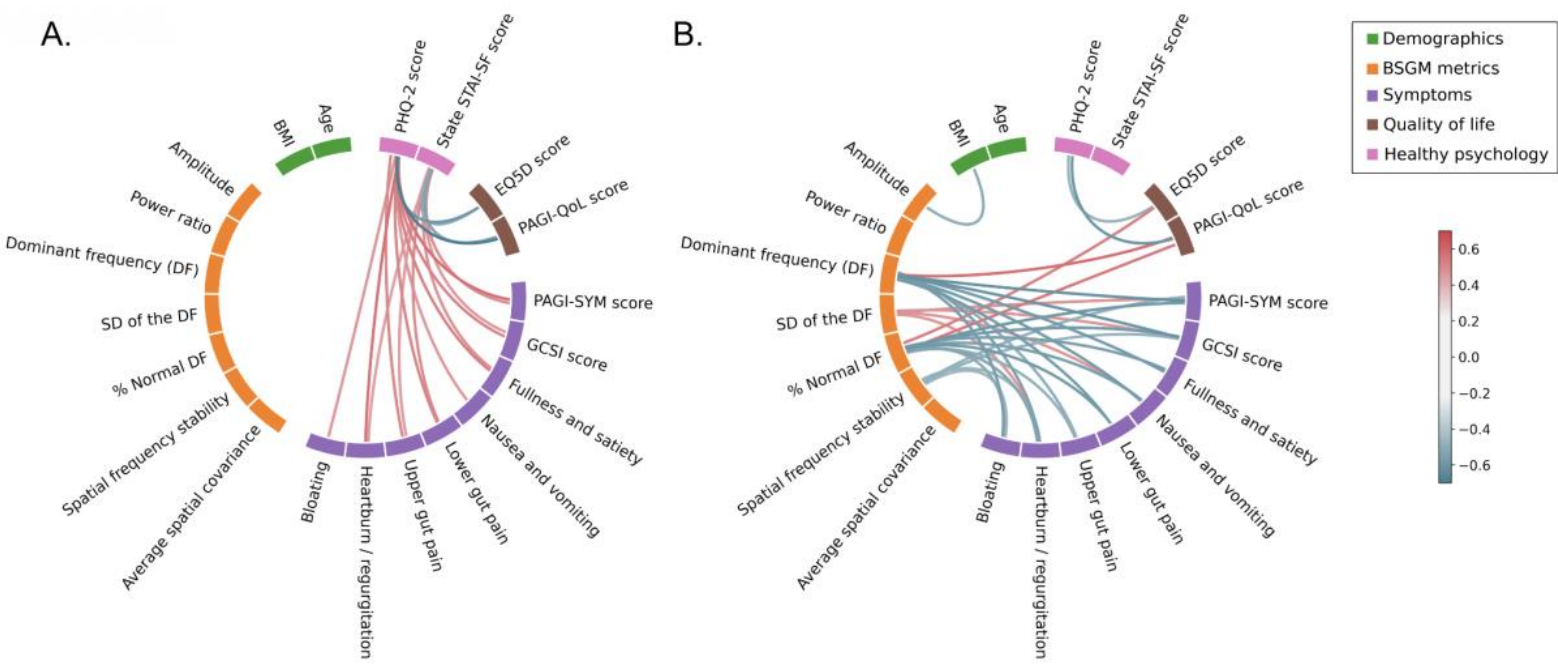

Wheel plot showing correlations between demographics, BSGM metrics, symptoms as measured by the PAGI-SYM subscales, quality of life and health psychology metrics in NSV groups. Correlations between quality of life metrics and symptoms are not reported, and only statistically significant correlations between categories are shown (after Hochberg correction). A: NVS-N cohort and controls; B: NVS-Abn cohort and controls.

BSGM, body surface gastric mapping, SD; standard deviation, DF; dominant frequency, GCSI; gastroparesis cardinal symptom index, PAGI-SYM, Patient Assessment of Upper Gastrointestinal Disorders-Symptom Severity Index; EQ5D; EuroQoL 5, EuroQoL 5D, PAGI-QoL; Patient Assessment of Upper Gastrolntestinal Disorders-Quality of Life, STAI-SF; State-Trait Anxiety Inventory Short Form, PHQ-2; Patient Health Questionnaire-2. 
medRxiv preprint doi: https://doi.org/10.1101/2022.02.07.22270514; this version posted February 8, 2022. The copyright holder for this preprint (which was not certified by peer review) is the author/funder, who has granted medRxiv a license to display the preprint in perpetuity.

Gastric Dysfunction in NVS

All rights reserved. No reuse allowed without permission.

\section{Supplementary Appendix}

\section{Methods}

\section{Gastric Alimetry® System}

Gastric Alimetry ${ }^{\circledR}$ is a novel medical device custom-designed for BSGM and detailed here in full for the first time. The device consists of an HR Array, wearable Reader, Dock, iPadOS App for setup and symptom logging, and cloud-based analytics and reporting platform (Fig. 1A). Key design considerations for each component are detailed below.

- Array. The Gastric Alimetry Array ${ }^{\mathrm{TM}}$ includes 66 pre-gelled $\mathrm{Ag} / \mathrm{AgCl}$ electrodes (8x8 grid +2 reference; inter-electrode spacing $20 \mathrm{~mm})$, covering an area of $21 \times 16 \mathrm{~cm}\left(196 \mathrm{~cm}^{2}\right)$ (Fig. 1B). This Array ${ }^{\mathrm{TM}}$ specification was designed to overlie the majority of the stomach's area in $>95 \%$ of cases, which is important because gastric position is highly variable and the weak gastric signal strength diminishes exponentially from source. ${ }^{48-50}$. Each Array is single-use, being screen printed using conductive inks on a single, flexible, thermoplastic polyurethane (TPU), with an overlying peel-and-stick adhesive layer that enables rapid setup and removal. ${ }^{27}$

- Reader. The Alimetry Reader ${ }^{\mathrm{TM}}$ incorporates custom-designed electronics specifically tuned for gastric electrophysiology (Fig. 1B). Signals are acquired at $250 \mathrm{~Hz}$, then amplified and digitized by low-noise programmable gain amplifiers, with each input compared against a common reference electrode to provide unipolar recordings, while movement artifacts are registered by an onboard accelerometer. The Reader attaches to the Array using a custom board-to-board connector design that eliminates all cabling to enable unimpeded wearability and facilitate ease of cleaning.

- Dock. The Alimetry Dock ${ }^{\mathrm{TM}}$ is used for charging and storage of the Reader, and accurate alignment of the Array during setup (Fig. 1B).

- App. The Gastric Alimetry App ${ }^{\mathrm{TM}}$ runs on an iPad mini (Apple, Cupertino, CA), and is used for device setup, data transfers, and to capture patient-reported symptom data during testing. Guided setup in the App includes an Array positioning step that tailors placement per individual patient biometrics, to further enhance accurate positioning over the stomach. ${ }^{27}$ Patients log symptoms every 15 minutes via a digital interface employing pictograms (Fig. 1A), which has been validated to enable reliable capture of patient symptom data in association with a standard 
medRxiv preprint doi: https://doi.org/10.1101/2022.02.07.22270514; this version posted February 8, 2022. The copyright holder for this preprint (which was not certified by peer review) is the author/funder, who has granted medRxiv a license to display the preprint in perpetuity.

meal with excellent compliance. ${ }^{34}$ This system therefore enables precise temporal correlations between patient symptom profiles with electrophysiological data.

- Cloud / Portal. Test data is transmitted to a HIPAA-compliant cloud server at the conclusion of each test. A proprietary algorithm automatically filters and analyzes raw myoelectrical signals to generate a report, including key metrics and data visualizations (detailed below), which are accessible via a secure online portal. Filtering methods are based on a previously validated scheme by Gharibans et al, accounting for accelerometer data. ${ }^{44}$

\section{Spatial and spectral data analytics}

\section{Spectral analysis}

Spectral metrics represent the bioelectrical slow-waves that coordinate gastric motility, as well as gastric contractile activity registered through an increase in signal power, and are visualized using spectral plots (Fig. 1D). ${ }^{31,51}$ They are comparable to traditional EGG metrics, but are substantially more accurate due to the higher signal-to-noise ratio (SNR) of BSGM, which is enabled by a greater coverage over the stomach's area, reliable positioning over the stomach to account for anatomical biodiversity, summation of spectral data over a large number of active sensors, use of modern bioamplifiers, and validated signal processing techniques to account for noise including competing biological sources. ${ }^{22,24,27,44,48}$ These metrics encompass mean amplitude (microvolts; $\mu \mathrm{V}$ ), dominant frequency (cycles per minute; cpm), standard deviation (SD) of the dominant frequency, and the power ratio (the ratio of the mean amplitude in the fed vs fasted phase). ${ }^{52}$ In this study, these variables were visualized for the entire test period, but calculated in statistical analyses based on the first $2 \mathrm{hr}$ postprandially, when gastric activity is typically most active and SNR is highest. ${ }^{27}$

\section{Spatial analysis}

These metrics encompass spatial descriptions of gastric electrophysiological activity, providing increased sensitivity by detecting abnormal gastric activation patterns. ${ }^{16,17,20,22,24,45}$ The spatial metrics assessed in this study were devised to measure wave propagation stability, which was previously shown to be abnormal in subsets of NVS patients in serosal HR mapping studies. ${ }^{16,17}$ These spatial metrics included the 'spatial frequency stability' (defined as the percentage of the recording during which there is a single dominant frequency across the mapped field), 'average spatial covariance' 
medRxiv preprint doi: https://doi.org/10.1101/2022.02.07.22270514; this version posted February 8, 2022. The copyright holder for this preprint (which was not certified by peer review) is the author/funder, who has granted medRxiv a license to display the preprint in

All rights reserved. No reuse allowed without permission.

Gastric Dysfunction in NVS

(defined as the average absolute value of the covariance between pairs of electrodes computed over the course of a recording).

\section{BSGM test interpretation framework}

Test quality was assessed by the consensus panel on a scale of 1 to 4 , incorporating the following features according to the Gastric Alimetry labeling.

a) successful stomach localization ( $>7$ electrodes localized within mapped fields $)^{27}$

b) impedance ( $<200 \mathrm{k} \Omega$ optimal; $<500 \mathrm{k} \Omega$ acceptable; $500+\mathrm{k} \Omega$ poor)

c) proportion of artifacts ( $<20 \%$ optimal; $<50 \%$ acceptable; $>50 \%$ interpret with caution)

- Tests of score 1 were excluded, tests of score 2 were included but with caution advised in classification as normal or abnormal, and tests of 3-4 were included with confidence.

Reference ranges and spatial metrics for BSGM are still under development, and have not yet achieved regulatory approval for the Gastric Alimetry device. Classifications of individual subjects as normal, abnormal or indeterminate tests were therefore undertaken by the consensus panel exclusively according to spectral analyses in this study. The following 3 features were employed, according to the Gastric Alimetry labeling and existing gastric electrophysiology literature:20,27,52,53

a) presence of a meal response (power ratio $>1.4$ compared to a baseline period)

b) presence of a clear and consistent dominant frequency band within the spectral plot

c) presence of a normal rhythm (stability typically within a range of $2.5-3.6 \mathrm{cpm}$ )

- Isolated stable high or low frequencies were not judged abnormal in this study. ${ }^{16,17,45}$

The application of this process is summarized in Supplementary Figure S1.

\section{Supplementary statistical methods}

Where there was missing data for components of PCA analysis, the average value of the cohort was taken and substituted (overall there were fewer than $n=4$ missing data points). 
medRxiv preprint doi: https://doi.org/10.1101/2022.02.07.22270514; this version posted February 8, 2022. The copyright holder for this preprint (which was not certified by peer review) is the author/funder, who has granted medRxiv a license to display the preprint in

perpetuity.
All rights reserved. No reuse allowed without permission.

Gastric Dysfunction in NVS

Gharibans \& Calder et al. 2022.

Table S1: Cohort demographics

\begin{tabular}{|c|c|c|c|c|c|}
\hline & & Healthy Control & NVS & Total & p \\
\hline Total N (\%) & & $43(50.0)$ & $43(50.0)$ & 86 & \\
\hline Age & Mean (SD) & $36.1(14.5)$ & $36.1(13.2)$ & $36.1(13.8)$ & 0.981 \\
\hline \multirow[t]{2}{*}{ Sex } & Female & $31(72.1)$ & $35(81.4)$ & $66(76.7)$ & 0.444 \\
\hline & Male & $12(27.9)$ & $8(18.6)$ & $20(23.3)$ & \\
\hline BMI & Mean (SD) & $23.7(4.0)$ & $24.9(4.6)$ & $24.3(4.3)$ & 0.200 \\
\hline \multirow[t]{2}{*}{ Site of recruitment } & Auckland & $35(81.4)$ & $34(79.1)$ & $69(80.2)$ & 1.00 \\
\hline & Calgary & $8(18.6)$ & $9(20.9)$ & $17(19.8)$ & \\
\hline \multirow[t]{5}{*}{ Ethnicity } & Caucasian & $21(48.8)$ & $36(83.7)$ & $57(77.9)$ & 0.016 \\
\hline & Māori or Pacific & $1(2.3)$ & $2(4.7)$ & $3(3.5)$ & \\
\hline & $\begin{array}{l}\text { Indigenous } \\
\text { Peoples of } \\
\text { Canada }\end{array}$ & - & $1(2.3)$ & - & \\
\hline & Asian & $8(18.6)$ & $2(4.7)$ & $10(11.6)$ & \\
\hline & Other & $13(30.2)$ & $2(4.7)$ & $15(17.4)$ & \\
\hline \multirow[t]{2}{*}{ Confirmed gastroparesis } & No & - & $21(48.8)$ & $64(74.4)$ & - \\
\hline & Yes & - & $22(51.2)$ & $22(25.6)$ & \\
\hline \multirow[t]{2}{*}{ IBS } & No & $41(95.3)$ & $38(90.5)$ & $79(92.9)$ & 0.433 \\
\hline & Yes & $2(4.7)$ & $4(9.5)$ & $6(7.1)$ & \\
\hline \multirow[t]{2}{*}{ Diabetes Mellitus } & No & $43(100.0)$ & $34(79.1)$ & $77(89.5)$ & 0.002 \\
\hline & Yes & & $9(20.9)$ & $9(10.5)$ & \\
\hline \multirow[t]{2}{*}{$\begin{array}{l}\text { Complications of Diabetes } \\
\text { Mellitus }\end{array}$} & No & $43(100.0)$ & $35(81.4)$ & $78(90.7)$ & 0.005 \\
\hline & Yes & & $8(18.6)$ & $8(9.3)$ & \\
\hline \multirow[t]{2}{*}{ Ischaemic Heart Disease } & No & $43(100.0)$ & $41(95.3)$ & $84(97.7)$ & 0.494 \\
\hline & Yes & & $2(4.7)$ & $2(2.3)$ & \\
\hline \multirow[t]{2}{*}{ Chronic Renal Failure } & No & $43(100.0)$ & $41(95.3)$ & $84(97.7)$ & 0.494 \\
\hline & Yes & & $2(4.7)$ & $2(2.3)$ & \\
\hline \multirow[t]{2}{*}{ Anxiety } & No & $42(97.7)$ & $28(66.7)$ & $70(82.4)$ & $\begin{array}{c}<0.00 \\
1\end{array}$ \\
\hline & Yes & $1(2.3)$ & $14(33.3)$ & $15(17.6)$ & \\
\hline \multirow[t]{2}{*}{ Depression } & No & $43(100.0)$ & $33(78.6)$ & $76(89.4)$ & 0.001 \\
\hline & Yes & & $9(21.4)$ & $9(10.6)$ & \\
\hline \multirow[t]{2}{*}{ PTSD } & No & $42(97.7)$ & $38(90.5)$ & $80(94.1)$ & 0.202 \\
\hline & Yes & $1(2.3)$ & $4(9.5)$ & $5(5.9)$ & \\
\hline
\end{tabular}


medRxiv preprint doi: https://doi.org/10.1101/2022.02.07.22270514; this version posted February 8,2022 . The copyright holder for this preprint (which was not certified by peer review) is the author/funder, who has granted medRxiv a license to display the preprint in perpetuity.

Gastric Dysfunction in NVS

All rights reserved. No reuse allowed without permission.

Gharibans \& Calder et al. 2022.

\begin{tabular}{|c|c|c|c|c|c|}
\hline Previous Surgery & No & $31(75.6)$ & $25(58.1)$ & $56(66.7)$ & 0.108 \\
\hline & Yes & $10(24.4)$ & $18(41.9)$ & 28 (33.3) & \\
\hline \multirow[t]{9}{*}{ Medications } & Prokinetics & - & $14(32.6)$ & $13(16.3)$ & \\
\hline & Anti-nausea & - & $16(37.2)$ & $16(18.6)$ & \\
\hline & Acid suppressant & $2(4.7)$ & $22(51.2)$ & $24(27.9)$ & $\begin{array}{c}<0.00 \\
1\end{array}$ \\
\hline & Opioids & - & $8(18.6)$ & $8(9.3)$ & - \\
\hline & Laxatives & - & $10(23.3)$ & $10(11.6)$ & - \\
\hline & \begin{tabular}{|l|} 
Anxiolytics, \\
antidepressants / \\
neuromodulators
\end{tabular} & - & $16(37.2)$ & $16(18.6)$ & - \\
\hline & Anti-spasmodics & - & $1(2.3)$ & $1(1.2)$ & - \\
\hline & Gabapentanoids & - & $5(11.6)$ & $5(5.8)$ & - \\
\hline & Other & $11(25.6)$ & $34(79.1)$ & $45(52.3)$ & - \\
\hline \multirow[t]{2}{*}{ OTC or Alternative Medications } & No & $42(97.7)$ & $42(97.7)$ & $84(97.7)$ & 1 \\
\hline & Yes & $1(2.3)$ & $1(2.3)$ & $2(2.3)$ & \\
\hline \multirow[t]{2}{*}{ Tobacco Use } & No & $42(97.7)$ & $37(86.0)$ & 79 (91.9) & 0.11 \\
\hline & Yes & $1(2.3)$ & $6(14.0)$ & $7(8.1)$ & \\
\hline \multirow[t]{2}{*}{$\begin{array}{l}\begin{array}{l}\text { Tobacco Use within last } 48 \\
\text { hours }\end{array} \\
\end{array}$} & No & $43(100.0)$ & $37(86.0)$ & $80(93.0)$ & 0.026 \\
\hline & Yes & & $6(14.0)$ & $6(7.0)$ & \\
\hline PAGI-SYM Score & Median (IQR) & $0.1(0.0$ to 0.3$)$ & 2.6 (2.0 to 3.3 ) & 0.8 (0.1 to 2.6$)$ & $\begin{array}{c}<0.00 \\
1\end{array}$ \\
\hline PAGI-QoL Score & Median (IQR) & 4.8 (4.7 to 5.0$)$ & 2.8 (1.7 to 3.7$)$ & 4.5 (2.8 to 4.8$)$ & $\begin{array}{c}<0.00 \\
1\end{array}$ \\
\hline Total Symptom Burden & Median (IQR) & $0.2(0.0$ to 0.9$)$ & 16.0 (9.1 to 22.8 ) & $2.0(0.1$ to 15.6$)$ & $\begin{array}{c}<0.00 \\
1\end{array}$ \\
\hline Meal completion (\%) & Median (IQR) & 100.0 (100.0 to 100.0$)$ & $90.0(70.0$ to 100.0$)$ & 100.0 (90.0 to 100.0$)$ & $\begin{array}{c}<0.00 \\
1\end{array}$ \\
\hline
\end{tabular}

$P$ values are from Fisher's exact or Chi square test for categorical variables and Student's t-test for normally distributed continuous variables (mean (SD)), and Mann-Whitney $U$ for non-normally distributed continuous variables (median (IQR)). Patients could be on multiple overlapping medications within each medication category.

CNVS, chronic nausea and vomiting syndrome; FD, functional dyspepsia; EPS, epigastric pain syndrome; PDS, postprandial distress syndrome. PAGI-SYM, patient assessment of gastrointestinal disorders symptom severity index; PAGI-QOL, patient assessment of upper gastrointestinal disorders - quality of life. 
medRxiv preprint doi: https://doi.org/10.1101/2022.02.07.22270514; this version posted February 8, 2022. The copyright holder for this preprint (which was not certified by peer review) is the author/funder, who has granted medRxiv a license to display the preprint in perpetuity.

Gastric Dysfunction in NVS

All rights reserved. No reuse allowed without permission.

Gharibans \& Calder et al. 2022.

Table S2: Symptoms, quality of life, spectral and spatial data between controls and phenotyped NVS patients

\begin{tabular}{|c|c|c|c|c|c|c|}
\hline & $\begin{array}{l}\text { Control } \\
(n=43)\end{array}$ & $\begin{array}{c}\text { Gastric } \\
\text { dysfunction } \\
(n=13)\end{array}$ & $\begin{array}{c}\text { Patient with } \\
\text { normal BSGM } \\
(n=26)\end{array}$ & \begin{tabular}{|c|}
$P$ (gastric \\
dysfunction vs \\
patients with \\
normal BSGM)
\end{tabular} & \begin{tabular}{|c|}
$P$ (healthy \\
controls vs \\
patient with \\
normal BSGM)
\end{tabular} & $\begin{array}{l}\mathrm{P} \text { (healthy } \\
\text { controls vs } \\
\text { gastric } \\
\text { dysfunction) }\end{array}$ \\
\hline PAGI-SYM Score & $\begin{array}{l}0.1(0.0 \text { to } \\
0.3)\end{array}$ & $\begin{array}{l}2.5(2.0 \text { to } \\
3.1)\end{array}$ & 2.5 (2.1 to 3.2$)$ & 0.97 & $<0.001$ & $<0.001$ \\
\hline Total symptom burden & $\begin{array}{l}0.2(0.0 \text { to } \\
0.9)\end{array}$ & $\begin{array}{l}11.7(3.4 \text { to } \\
23.1)\end{array}$ & $\begin{array}{l}16.2(11.0 \text { to } \\
27.6)\end{array}$ & 0.62 & $<0.001$ & $<0.001$ \\
\hline GCSI & $\begin{array}{l}0.1(0.0 \text { to } \\
0.4)\end{array}$ & $\begin{array}{c}2.7(2.1 \text { to } \\
3.7)\end{array}$ & $3.1(2.8$ to 3.6$)$ & 0.49 & $<0.001$ & $<0.001$ \\
\hline EQ-5D & $\begin{array}{c}1.0(1.0 \text { to } \\
1.0)\end{array}$ & $\begin{array}{c}0.8(0.8 \text { to } \\
0.9)\end{array}$ & $0.8(0.7$ to 0.9$)$ & 0.1 & $<0.001$ & 0.006 \\
\hline PAGI-QoL Score & $\begin{array}{l}4.8(4.7 \text { to } \\
5.0)\end{array}$ & $\begin{array}{l}3.5(1.8 \text { to } \\
3.7)\end{array}$ & $2.4(1.6$ to 3.4$)$ & 0.27 & $<0.001$ & $<0.001$ \\
\hline Meal completion (\%) & $\begin{array}{c}100(100 \text { to } \\
100)\end{array}$ & $\begin{array}{c}100(70 \text { to } \\
100)\end{array}$ & $\begin{array}{l}95.0(70.0 \text { to } \\
100.0)\end{array}$ & 1.00 & 0.01 & 0.06 \\
\hline Amplitude & $\begin{array}{c}38.0(23.9 \text { to } \\
63.2\end{array}$ & $\begin{array}{c}20.6(18.1 \text { to } \\
24.8)\end{array}$ & $\begin{array}{l}26.7(21.4 \text { to } \\
36.1)\end{array}$ & 0.004 & 0.11 & 0.25 \\
\hline $\begin{array}{l}\text { Variance of the dominant } \\
\text { frequency }\end{array}$ & $\begin{array}{c}0.40(0.3 \text { to } \\
0.7)\end{array}$ & $\begin{array}{c}0.81(0.73 \text { to } \\
0.95)\end{array}$ & $\begin{array}{c}0.54(0.31 \text { to } \\
0.86)\end{array}$ & $<0.001$ & 0.18 & 0.04 \\
\hline $\begin{array}{l}\text { Percentage duration of } \\
\text { recording in the normal } \\
\text { gastric frequency }(2.5- \\
3.6 \mathrm{cpm})\end{array}$ & \begin{tabular}{|c|}
$81.6(63.1$ to \\
$92.0)$
\end{tabular} & $\begin{array}{c}31.3(27.3 \text { to } \\
51.7)\end{array}$ & $\begin{array}{c}76.4(23.5 \text { to } \\
89.4)\end{array}$ & $<0.001$ & 0.07 & 0.04 \\
\hline Power ratio & $\begin{array}{c}1.59(1.1 \text { to } \\
2.0)\end{array}$ & $\begin{array}{c}1.04(1.0 \text { to } \\
1.2)\end{array}$ & $1.4(1.1$ to 1.8$)$ & 0.014 & 0.43 & 0.18 \\
\hline Spatial frequency stability & \begin{tabular}{|c|}
$49.5(19.1$ to \\
$79.0)$
\end{tabular} & $\begin{array}{c}5.17 \text { (3.3 to } \\
10.2)\end{array}$ & $\begin{array}{c}38.0(14.7 \text { to } \\
56.3)\end{array}$ & $<0.001$ & 0.23 & 0.004 \\
\hline $\begin{array}{l}\text { Average spatial } \\
\text { covariance }\end{array}$ & $\begin{array}{c}0.52(0.49 \text { to } \\
0.54)\end{array}$ & $\begin{array}{c}0.47(0.46 \text { to } \\
0.51)\end{array}$ & $\begin{array}{l}0.50(0.47 \text { to } \\
0.53)\end{array}$ & 0.003 & 0.14 & 0.7 \\
\hline
\end{tabular}

*All metrics in this study were measured during the first 2-hours of postprandial recording where the SNR is typically highest (refer Supplementary Methods). All data are reported as median (IQR). BSGM, body surface gastric mapping. Post-hoc Tukey test adjusted $p$ values are reported. 
medRxiv preprint doi: https://doi.org/10.1101/2022.02.07.22270514; this version posted February 8, 2022. The copyright holder for this preprint (which was not certified by peer review) is the author/funder, who has granted medRxiv a license to display the preprint in perpetuity.

Gastric Dysfunction in NVS

All rights reserved. No reuse allowed without permission.

Gharibans \& Calder et al. 2022.

Table S3: Artifact and impedance measures

\begin{tabular}{|l|l|c|c|c|c|}
\hline & & Control & Patient & Total & p \\
\hline Total N (\%) & & $43(50.0)$ & $43(50.0)$ & 86 & \\
\hline Marked artifact & Median (IQR) & $8.1(4.0$ to 11.4$)$ & $15.5(7.6$ to 24.6$)$ & $9.7(5.1$ to 18.2$)$ & $<0.001$ \\
\hline Impedance & Mean (SD) & $95.6(55.9$ to 134.1$)$ & $122.5(83.9$ to 182.7$)$ & $112.3(63.3$ to 154.1$)$ & 0.028 \\
\hline
\end{tabular}

Table S4: Delayed gastric emptying status by phenotyped subgroup

\begin{tabular}{|l|l|c|c|c|c|}
\hline & & Control & NVS-N & NVS-Abn & p \\
\hline Confirmed gastroparesis & No & $43(100.0)$ & $9(34.6)$ & $10(76.9)$ & $<0.001$ \\
\hline & Yes & $0(0.0)$ & $17(65.4)$ & $3(23.1)$ & \\
\hline
\end{tabular}


medRxiv preprint doi: https://doi.org/10.1101/2022.02.07.22270514; this version posted February 8, 2022. The copyright holder for this preprint (which was not certified by peer review) is the author/funder, who has granted medRxiv a license to display the preprint in perpetuity.

Gastric Dysfunction in NVS

All rights reserved. No reuse allowed without permission.

Gharibans \& Calder et al. 2022.

\section{Supplementary Figures}

\section{Figure S1}

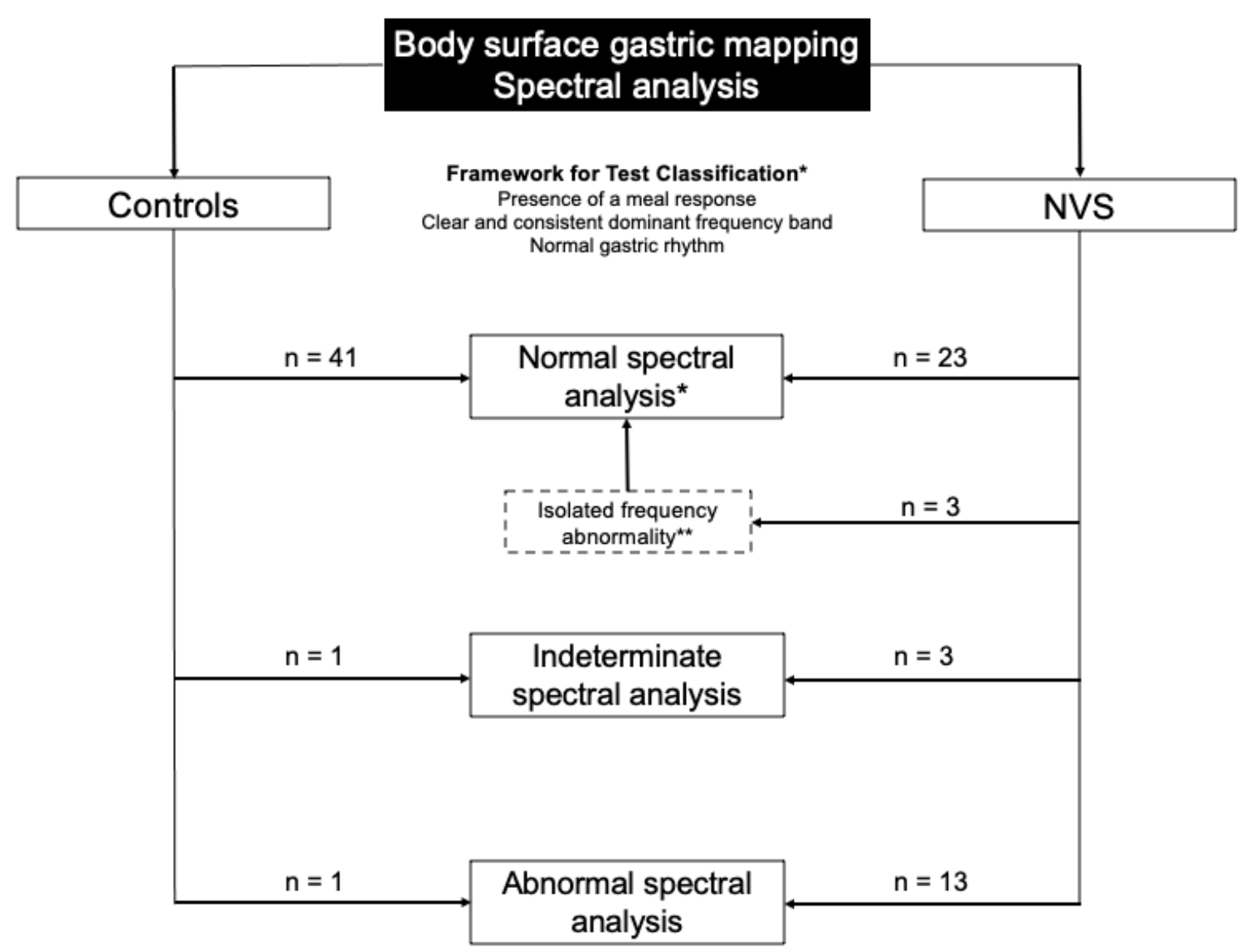

Classification scheme employed for controls and NVS patients. Among the participants that had a normal spectral analysis, there were several variants of normal characterized by either: high fasting baseline power $(n=4)$, limited meal response $(n=2)$, delayed-onset meal response $(n=5)$, or transient spectral abnormalities $(n=2)$. One NVS patient was excluded due to inadequate test quality. Data on variants and the excluded subject are provided in Fig. S4. 
medRxiv preprint doi: https://doi.org/10.1101/2022.02.07.22270514; this version posted February 8, 2022. The copyright holder for this preprint (which was not certified by peer review) is the author/funder, who has granted medRxiv a license to display the preprint in perpetuity.

Gastric Dysfunction in NVS

All rights reserved. No reuse allowed without permission.

Gharibans \& Calder et al. 2022.

Figure S2
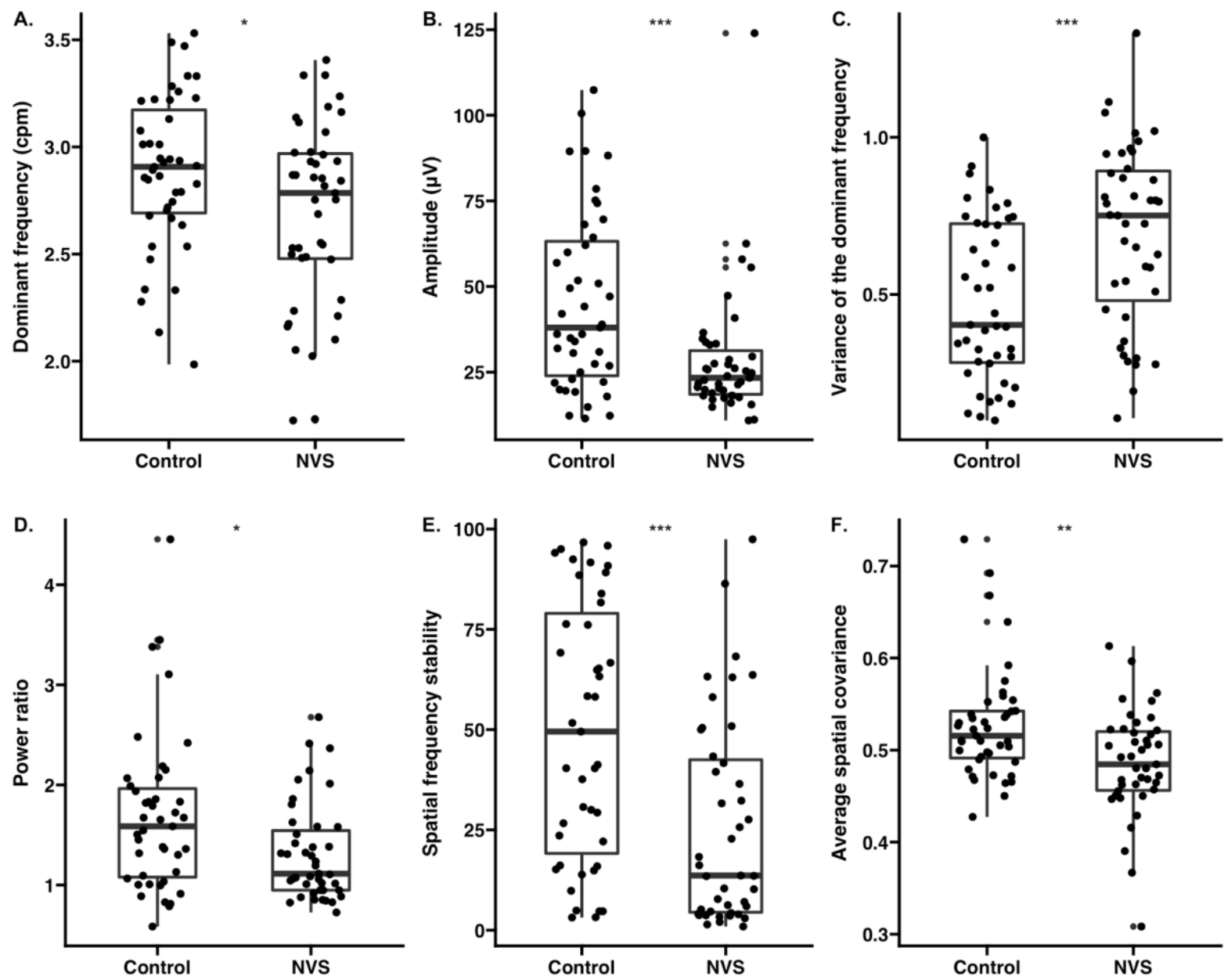

Box plots of symptoms and BSGM metrics in controls and NVS patient cohorts.

cpm: cycles per minute; NVS: nausea vomiting syndrome. 
medRxiv preprint doi: https://doi.org/10.1101/2022.02.07.22270514; this version posted February 8, 2022. The copyright holder for this preprint (which was not certified by peer review) is the author/funder, who has granted medRxiv a license to display the preprint in perpetuity.

Gastric Dysfunction in NVS

All rights reserved. No reuse allowed without permission.

Gharibans \& Calder et al. 2022.

\section{Figure S3}

A. Healthy controls with normal spectral data $(n=43)$
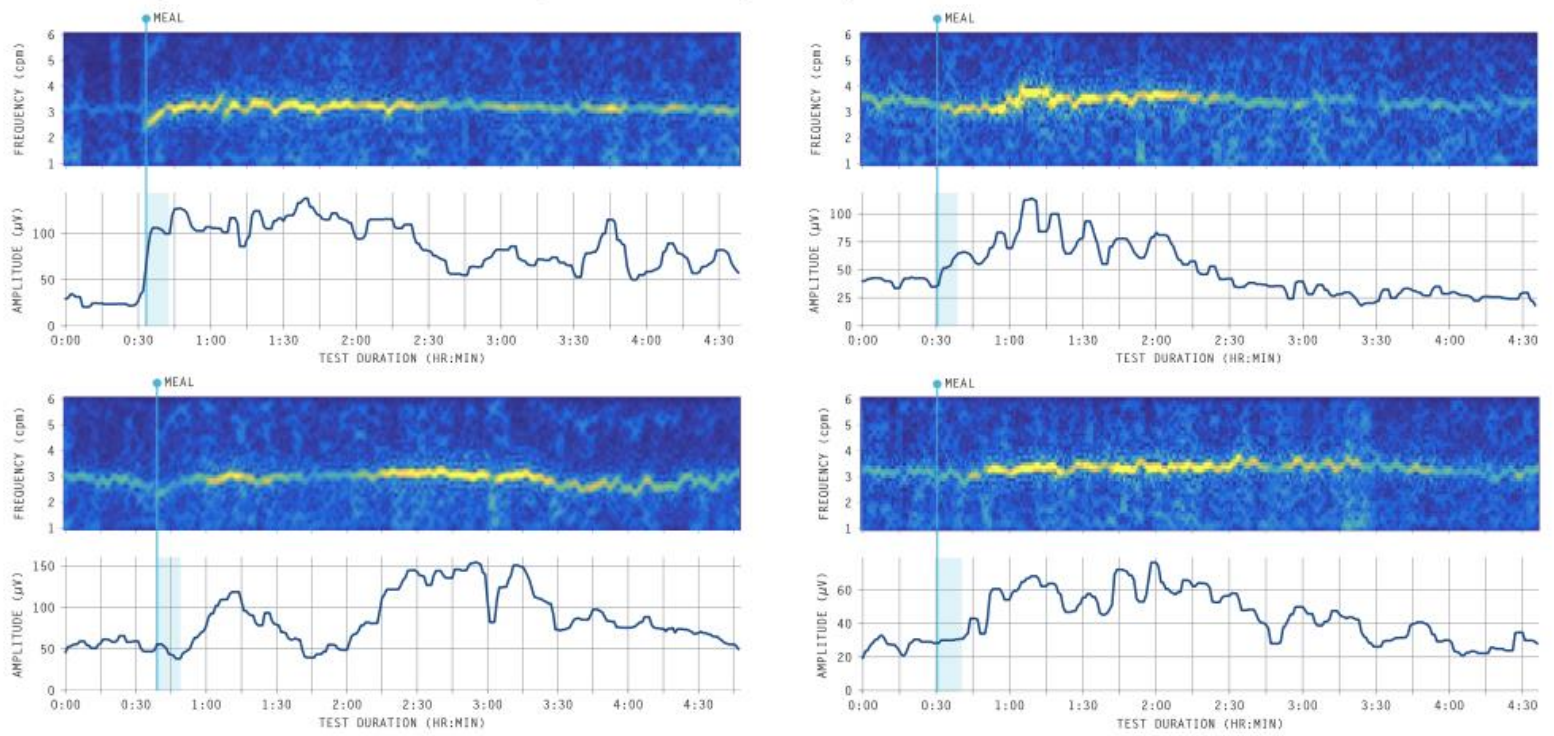

B. Nausea and vomiting syndrome patient with normal spectral data $(n=26)$
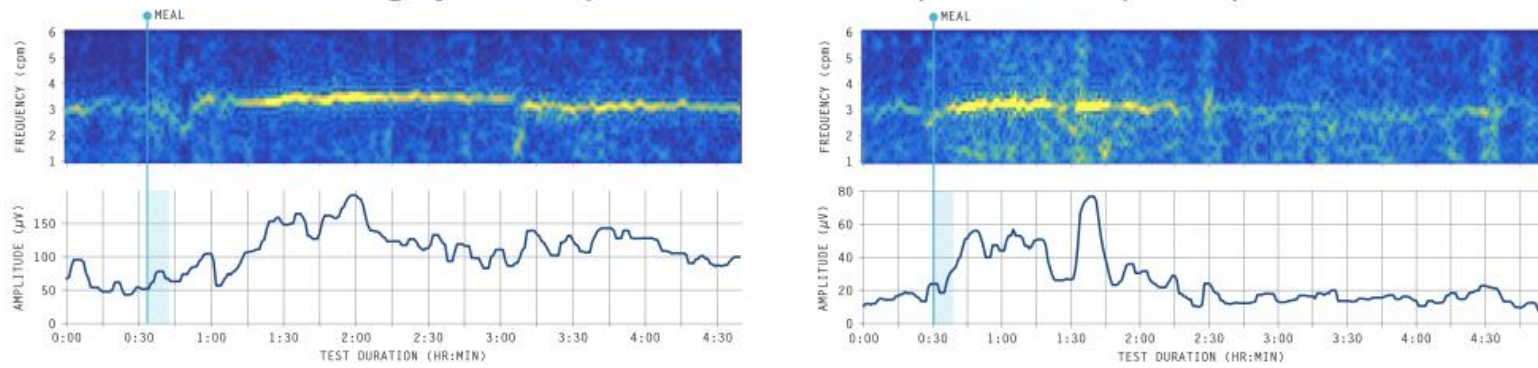

C. Nausea and vomiting syndrome patient with abnormal spectral data $(n=13)$
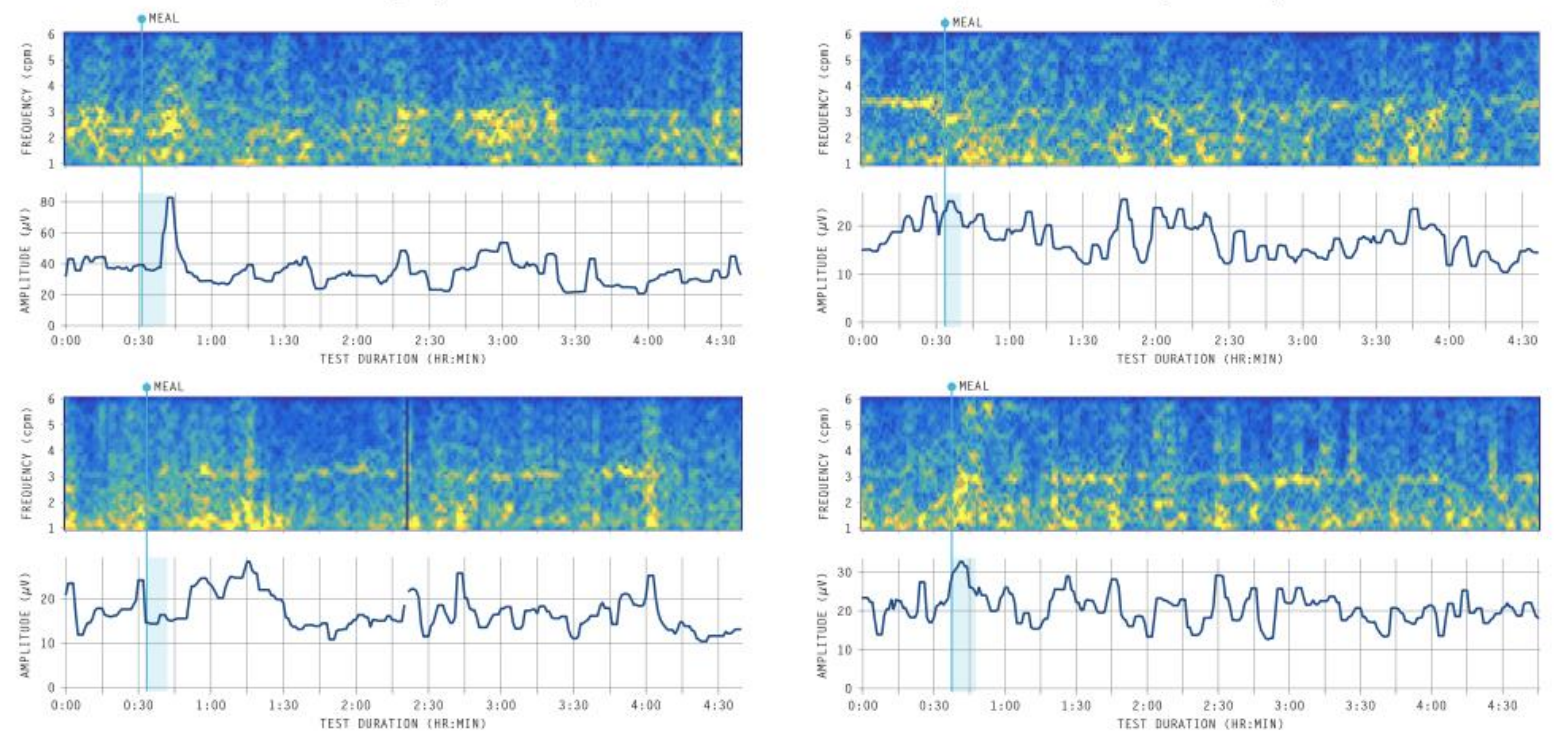

BSGM spectral plots (frequency-amplitude graphs), showing dominant frequencies on a scale from low power (dark blue) to high power (bright yellow), indicating gastric meal responses and rhythm, and with amplitude plots beneath. The meal time and duration is indicated by a vertical blue bar. 
medRxiv preprint doi: https://doi.org/10.1101/2022.02.07.22270514; this version posted February 8, 2022. The copyright holder for this preprint (which was not certified by peer review) is the author/funder, who has granted medRxiv a license to display the preprint in perpetuity.

Gastric Dysfunction in NVS All rights reserved. No reuse allowed without permission.

Gharibans \& Calder et al. 2022.

Normal spectral plots $(\mathbf{A}, \mathbf{B})$ show a clear meal response (post-prandial power increase), a consistent and sustained frequency band, and a regular gastric rhythm (Supplementary Methods and Fig. S1). C) Abnormal cases lack these features. Examples of normal variants are provided in Fig. S4. 
medRxiv preprint doi: https://doi.org/10.1101/2022.02.07.22270514; this version posted February 8, 2022. The copyright holder for this preprint (which was not certified by peer review) is the author/funder, who has granted medRxiv a license to display the preprint in perpetuity.

Gastric Dysfunction in NVS

All rights reserved. No reuse allowed without permission.

Gharibans \& Calder et al. 2022.

\section{Figure S4}

A. Normal variant: high fasting baseline power

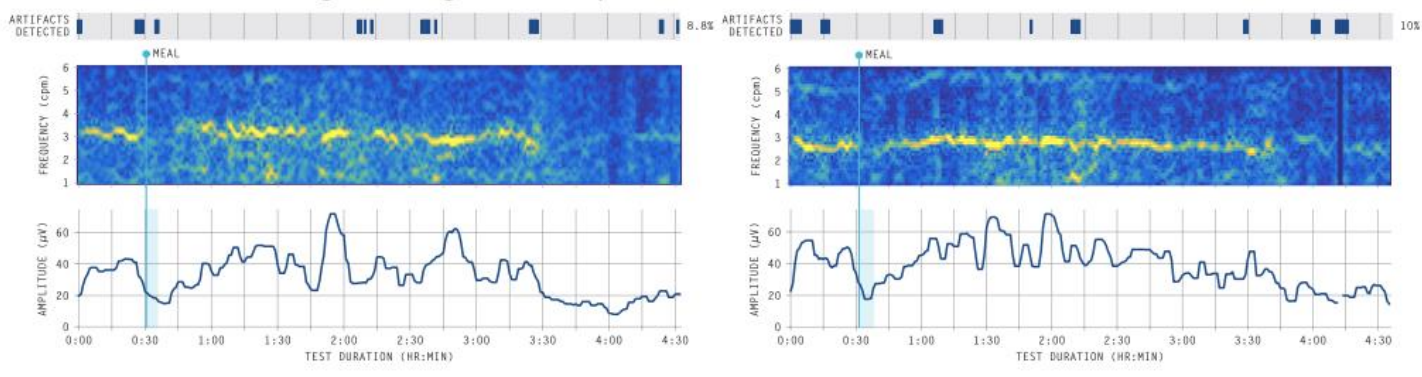

B. Normal variant: limited meal response
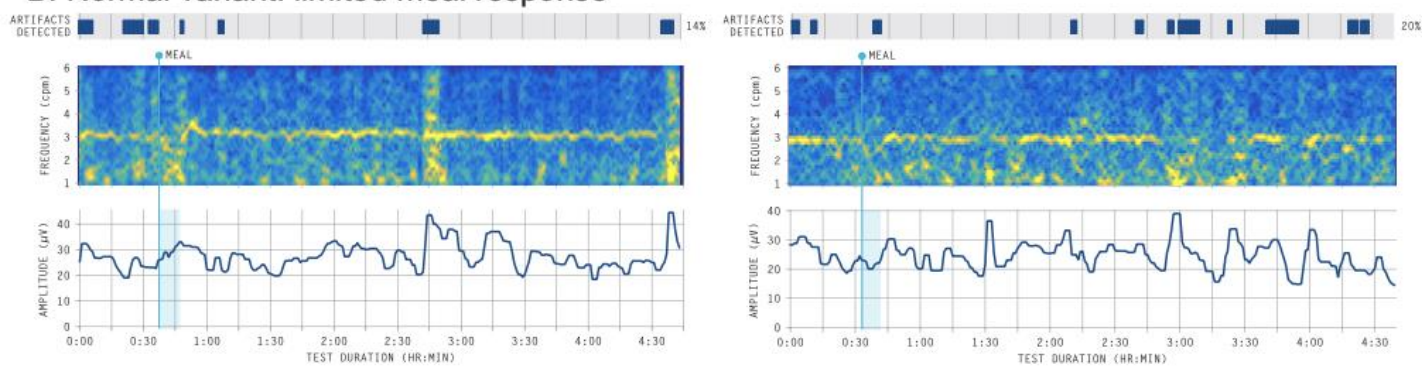

C. Normal variant: delayed-onset meal response
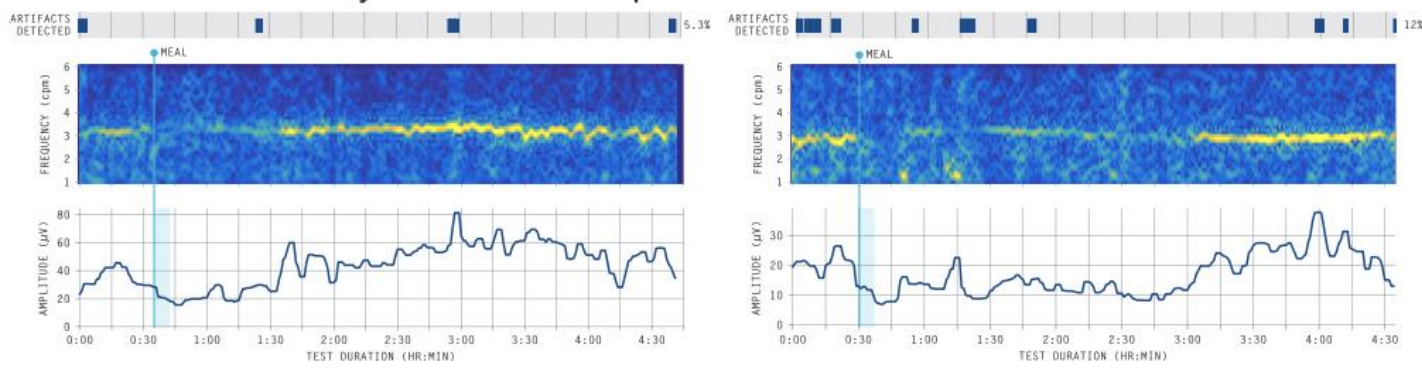

D. Stable isolated high frequency

E. Transient spectral abnormality
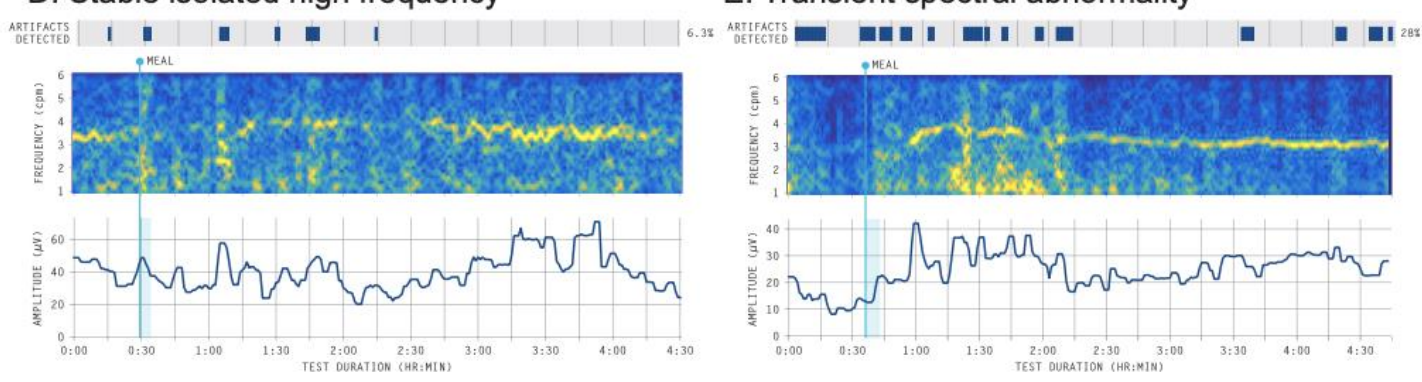

BSGM spectral plots (frequency-amplitude graphs) showing atypical data. Three variations of normal were observed in control data, as follows: A) High fasting baseline power $(n=4)$; B) Limited meal response ( $n=2$; no post-prandial power increase observed, but strong dominant frequency band with normal rhythm); C) Delayed-onset meal response $(n=5)$. In addition, two types of abnormalities were seen in patients that did not reach threshold for an abnormal classification in this study, but were not observed in controls and may represent pathological variations: D) Isolated stable high frequencies ( $n=3$; range $3.8-4.0 \mathrm{cpm})$; E) Transient spectral abnormalities $(n=2)$. 
medRxiv preprint doi: https://doi.org/10.1101/2022.02.07.22270514; this version posted February 8, 2022. The copyright holder for this preprint (which was not certified by peer review) is the author/funder, who has granted medRxiv a license to display the preprint in perpetuity.

Gastric Dysfunction in NVS

All rights reserved. No reuse allowed without permission.

Gharibans \& Calder et al. 2022.

\section{Figure S5}

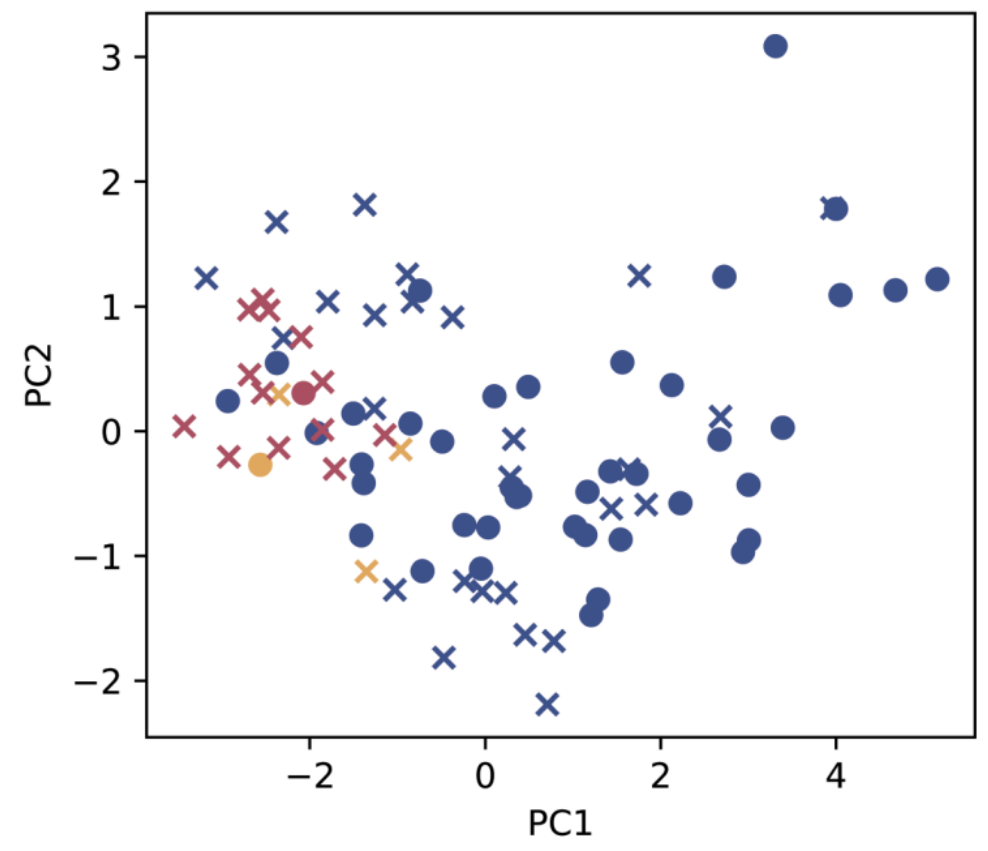

Control: Normal test

- Control: Indeterminate

- Control: Abnormal test

$\times$ Patient: Normal test

$\times$ Patient: Indeterminate

$\times$ Patient: Abnormal test

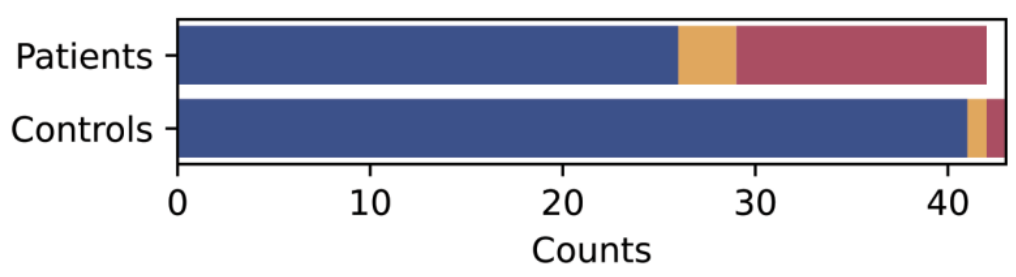

Normal

Indeterminate

Abnormal

Principal component analysis including only body surface gastric metrics. 
medRxiv preprint doi: https://doi.org/10.1101/2022.02.07.22270514; this version posted February 8, 2022. The copyright holder for this preprint (which was not certified by peer review) is the author/funder, who has granted medRxiv a license to display the preprint in perpetuity.

Gastric Dysfunction in NVS

All rights reserved. No reuse allowed without permission.

Gharibans \& Calder et al. 2022.

\section{Figure S6}

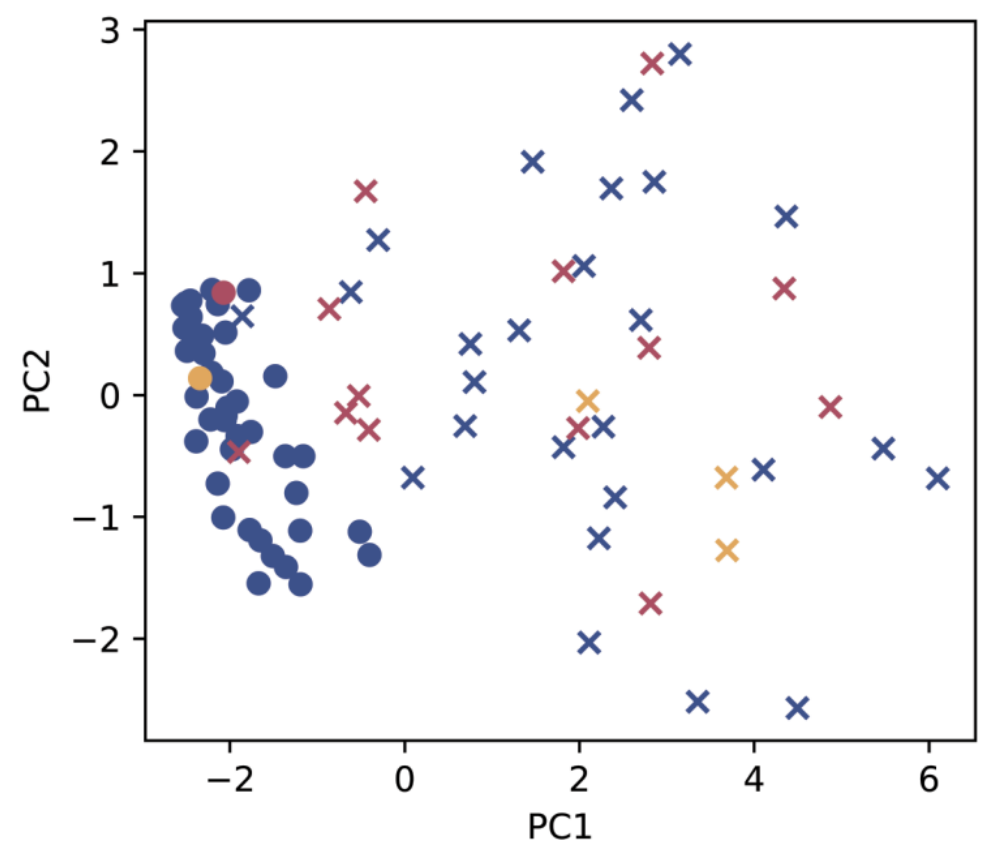

- Control: Normal test

Control: Indeterminate

- Control: Abnormal test

$x$ Patient: Normal test

$\times$ Patient: Indeterminate

$\times$ Patient: Abnormal test

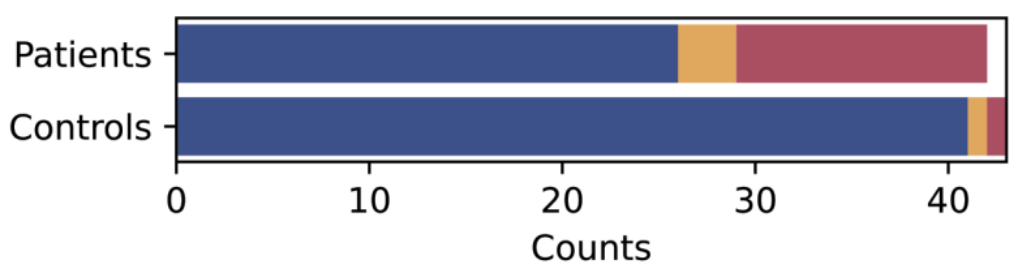

Normal

Indeterminate

Abnormal

Principal component analysis including only symptoms and psychological data. 